ÇOMÜ Uluslararası Sosyal Bilimler Dergisi 3 (2), 233-263 , 2018

COMU International Journal of Social Sciences 3 (2), 233-263, 2018

\title{
Küçük ve Orta Büyüklükteki İşletmelerde İnovasyona Yönelik Tutumlar ve İnovasyon Engelleri: Çanakkale İlinde KOBİ'ler Üzerine Bir Araştırma *
}

\begin{abstract}
Ahmet ŞAHBAZ ${ }^{\bullet * *}$ Mustafa TANYERI ${ }^{* * *}$

Öz

İşletmelerin rekabet gücünün ve verimliliklerinin artırılmasında, inovasyon çok önemli bir araçtır. İnovasyon sayesinde maliyetlerini düşürebilen işletmeler; fiyat avantajı, rakipleri karşısında farkındalık ve üstün kalite gibi avantajlar elde edebilmektedir. Büyük ölçekli işletmelerin rakibi durumunda olan KOBİ’ler; ürünlerinde, süreçlerinde, pazarlama yöntem ve tekniklerinde, organizasyon yapılarında inovasyondan faydalanmak durumundadırlar.

Çalışmanın amacı; KOBİ’lerin inovasyona yönelik tutumlarının belirlenmesi, inovasyon uygulamalarını engelleyen işletme içi ve dışı faktörlerin tespit edilmesine yöneliktir. Belirtilen bu faktörler arasındaki ilişki ve ilişki boyutları incelenmeye çalışılmıştır. Bu amaçla Çanakkale ili ve çevresinde faaliyet gösteren 132 KOBİnin sahipleri ve çeşitli kademelerdeki yöneticilerinin görüşleri anket uygulaması yöntemiyle alınmış ve analiz edilmiştir.
\end{abstract}

Anahtar Kelimeler: Küçük ve Orta Büyüklükteki İşletmeler, İnovasyon,İnovasyon Tutumları, İnovasyon Stratejileri, İnovasyon Engelleri.

* $\quad$ Bu makale Ahmet Şahbaz tarafından Prof Dr. Mustafa Tanyeri danışmanlığında Dokuz Eylül Üniversitesi Sosyal Bilimler Enstitüsünde 19.10.2017 tarihinde kabul edilen, “ Küçük ve Orta Büyüklükteki İşletmelerde İnovasyona Yönelik Tutumlar ve İnovasyon Engelleri: Çanakkale İlinde Kobi’ler Üzerine Bir Araştırma” adlı doktora tezinin literatür ve analiz kısımlarından yararlanılarak hazırlanmıştır.

(C) Sorumlu Yazar / Corresponding Author

** Öğretim Görevlisi Dr., Çanakkale Onsekiz Mart Üniversitesi, Yenice Meslek Yüksekokulu, asahbaz@comu. edu.tr

*** Prof Dr., Dokuz Eylül Üniversitesi İşletme Fakültesi, İşletme Bölümü, mustafa.tanyeri@deu.edu.tr 


\title{
The Innovation Barriers and Attitudes towards Innovation at SMEs: A Study on SMEs in Çanakkale
}

\begin{abstract}
Innovation is a very important tool in increasing companies' competitiveness and efficiency. The companies - who decrease their costs through innovation- gain advantage such as; prise advantage, awareness and higher quality, against their rivals.SMEs who are the rivals of big companies, must benefit from innovation at their products, processes, marketingmethods and techniques and organization structures.

The aim of this study is to determine the SMEs attitudes towards innovation and internal and external factors that prevent/block the innovation applications. The dimensions of the relationship and the relationship between the given factors are tried to be investigated. Forthis, 132 SMEs owners and up level managers' opinions operating in Çanakkale are collected and analyzed through a questionnaire.
\end{abstract}

Keywords: Small and Medium Sized Firms, Innovation, Innovation Attitudes, Innovation Strategies, Innovation Barriers.

\section{GİRIş}

Küreselleşme süreciyle birlikte sınırların ortadan kalkmasıyla dünya tek pazar haline gelmiş, işletmelerin bu pazarda rakipleri artmıştır. Dolayısıyla işletmeler için rekabet aynı bölge ve aynı pazar olmaktan çıkarak uluslararası boyuta taşınmıştır. Yoğun ve değişken rekabet ortamında faaliyet gösteren işletmelerin ayakta kalabilmeleri ürün ve hizmetlerini, üretim yöntemlerini sürekli değiştirmeleri ya da yenilemeleriyle mümkündür. Budurum ise, sınırlı kaynaklara sahip, ekonomik ve teknik açıdan hızla değişen dinamik çevrede faaliyetlerini yürüten ve pazar payları da çok geniş olmayan Küçük ve Orta Büyüklükteki İşletmeleri (KOBİ) daha fazla etkilemiş olacaktır.

Günümüzde hem işletmeler hem de ülkeler açısından dünyada gerçekleşen değişimin farkında olmak ve değişime ayak uydurabilmek önemli bir husustur. Bu değişim sürecinde inovasyon önemi artan kavramlardan birisi olmuştur. Ülkeler rekabetçi ve dinamik bilgi ekonomisine ulaşma hedeflerinde inovasyon ve inovasyon politikalarına önem vermek durumundadırlar. KOBİ’ler açısından inovasyon kavramının her geçen gün önemi artmaktadır. Ayrıca KOBİ’lerin inovasyona yönelik bazı avantajları bulunmaktadır. Bu avantajlar, KOBİlerin büyük işletmelere göre değişime daha hızlı adapte olabilmesi, hızlı istihdam potansiyelini bünyelerinde barındırabilmesi, ürün ve hizmet çeşitliliği sunabilmesi, kısıtlı yatırım koşullarında üretim yapabilmesi şeklinde sıralanabilir. 
Ülkemizde işletmelerin büyük bir oranı(\%99) KOBİ’lerden oluşmaktadır. Bu nedenle ekonomik ve sosyal gelişmenin kaynağı ve kalkınmanın temelini oluşturan KOBİlerin güçlendirilmesi önem arz etmektedir. Buna yönelik olarak KOBİ’lerin teknolojiyi kullanarak, ekonomiye daha fazla uyum ve inovasyon ile hızlı büyüme trendi sağlamaları gerekmektedir. Böylece KOBİlerin rekabet yaratmaları sonucu verimlilikleri artacaktır. İstihdam açısından da ekonomiye olumlu katkıları olacaktır. Diğer taraftan inovasyon bazı işletmelerde başarılı bir şekilde uygulanırken, bazılarında ise uygulanamamaktadır. Bazı işletmeler inovatif olurken bazıları olamamaktadır. Bu bağlamda KOBİ’lerin inovasyon tutumları ve inovasyon engellerinin belirlenmesi önem taşımaktadır.

\section{INNOVASYON KAVRAMI}

İnovasyona yönelik çok sayıda ve farklı yazarlar tarafından oluşturulmuş tanım bulunmaktadır. Bu nedenle inovasyon homojen bir kavram olma özelliği taşımamaktadır. Farklı yazarlar ilişkili buldukları unsurlar üzerinde durarak, yeni tanımlar yapmışlardır. Örneğin, inovasyonla ilgili çok sayıdaki tanım üzerine yapılan incelemede şu sonuçlar elde edilmiştir: Araştırmacıların büyük bir çoğunluğu inovasyonla ilgili açık bir tanım oluşturmayı başaramamıştır. Ayrıca inovasyon kavramına yönelik kullanılan tanımların birçok gruplara ayrılabilmesi söz konusudur. Tanımlarda belirtilen hususların uzun vadede değişebilmesi olasılığı söz konusudur (Gündüz, 2012: 89-90).

İnovasyon (innovation), Latince “innovatus” sözcügünden türemiştir. Yeni yöntemlerin idari, kültürel ve toplumsal alanlarda uygulanmaya başlanması anlamını taşımaktadır. Webster, inovasyonu farkl1, yeni sonucun elde edilmesi boyutunda değerlendirmiştir.

Türkçe literatürde, Türk Dil Kurumunun (2007) oluşturduğu yenilik, yenilikçilik, yenilenme ve "yenileșim" kelimelerinin tercih edildiği görülmektedir. Fakat bu durum gerçek anlamın karşılığını tam olarak vermemektedir. Ekonomik ve toplumsal bir sistemin farklılaştırılması ve değiştirilmesi inovasyonun sonucunu göstermektedir. Bu durum inovasyonun kendisinden daha fazla önem taşımaktadır (Elçi, 2006: 1). İnovasyon; yeni yönetim, ticarileștirme, organizasyon, bilgi işlem ve finansman yöntemlerini bulma ve uygulamaya yöneliktir. Dolayısıyla buluş, var olmayanı yaratmak, inovasyon ise yaratıcı bir süreçtir (Sat1, 2013: 18 ). İnovasyon anlam olarak bir şeyin eskisinden kurtuluşu olarak da anlaşılmaktadır. Oysa inovasyon kavramı daha geniş bir tanımlamayı içermektedir. Örneğin inovasyon piyasada alıcısı bulunan her ürün için söz konusudur. Diğer taraftan bir ürünün eski modelinin, ürün üzerinde farklılıklar oluşturularak tekrar müşteriye satılması da inovasyon olarak tanımlanır (Keskin, 2012: 17).

Cumming (1998)'e göre (aktaran Gündüz, 2012: 90) inovasyon, bir ürün ya da süreçteki başarının elde edildiği ilk uygulamadır. Davis ve Devinney (1996) (aktaran Gündüz, 2012: 90) inovasyonu daha değişik bir tanımla değerlendirmişlerdir. İnovasyon, yeni ya da farklı bir çözüm yolunun yeni ya da var olan bir problemi ve ihtiyacı karşılaması olarak bu tanımla belirtilmektedir. Bu bilim adamları yapmış oldukları bu tanımın "yeni ürünler, yeni üretim süreçleri, yeni malzemeler ve kaynaklar, yeni pazarlar ve yeni organizasyon 
biçimleri” gibi geleneksel inovasyon tanımlarının büyük bir çoğunluğunu kapsadığını ifade etmektedirler.

İnovasyonun sağlayacağı yararlar kişiler, gruplar ve organizasyonlar boyutunda değerlendirilmelidir. Gronhaug ve Kaufman’a (1988) göre (aktaran Tokmak, 2008: 55) inovasyonun gerçekleşebilmesinde inovasyonun yararlı olması ya da yararlı olacağı algısı önem taşımaktadır. Yararlı olmak; kişilere, gruplara ve organizasyonlara ekonomik fayda sağlamak olarak açıklanabilir. Coopey ve diğerlerine göre (1998) (aktaran Tokmak, 2008: 55) inovasyon özellikle "yeni bir şey"in başlangıcı olarak kabul edilmektedir. Ayrıca inovasyon bir değişim süreci olarak görülmektedir. Belirtilen "yeni bir şey”; ürün, hizmet, teknoloji, yatırım uygulamaları veya işletmelerdeki idari süreçlerden oluşmaktadır. Furman ve diğerlerine göre ise (2002) (aktaran Tokmak, 2008: 55-56) inovasyon yeni ürünler, üretim süreçleri ve hizmetler ortaya çıkarılması ve pazarlanmasıdır. Belirtilmesi gereken önemli husus inovasyon için her zaman yeni bir ürüne veya hizmete gereksinim duyulmamasıdır. Geçmişte farklı amaçlarla üretilen bir ürünün, hizmetin ya da sürecin farklı bir alanda yeniden pazarlanması mümkün olabilmektedir. Belirtilen bu durum da inovasyon olarak kabul edilmektedir.

Drucker, büyük bir işletmenin de inovasyon yapması gerektiğini belirtmiştir. Aksi durumda büyük bir işletmenin, küçülebileceğini ve yok olabileceğini ifade etmiştir. Motorola CEO’su Jeff İmmelt ise kârlılığın tek kaynağının inovasyon olduğunu vurgulamıştır. Jeff İmmelt göre bugün ve gelecekte işletmelerin yatırım yapmasının tek nedeni inovasyondur. Burada işletmelerin inovasyon yapabilme ve farklılık oluşturabilme yetenekleri ön plana çıkmaktadır. Japonya Başbakanı Junichiro Koizumi, Japonya için yeniden doğuşun, sürekli inovasyon ve insan kapasitesiyle sağlanabileceğini belirtmiştir (Işık ve Keskin, 2013: 44-46).

\section{2. İNOVASYON TÜRLERİ}

İnovasyon en yalın tanımıyla son teknolojilerin uygulanması ve yeni ürün ve hizmetlerin üretilmesidir. Diğer taraftan inovasyon yeni pazarlara ulaşmanın ve organizasyonel yapıda meydana gelen değişimlerin yanında ürün ve süreçlerdeki artırımsal inovasyonları da içermektedir. Bu bağlamda yeni ürün, yeni üretim süreci teknolojisi, yeni bir yapı, yönetimsel sistem ya da organizasyon üyelerine sağlanan yeni bir plan da inovasyon olarak değerlendirilebilmektedir. Yani inovasyon sadece ürünler için değil süreçlerde, dağıtımda, müşteri deneyiminde, markada ve iş modelinde de yapılabilmektedir (Taşkın ve Kahraman, 2016: 538). Bu bağlamda literatürde çok sayıda inovasyon türleri yer almasına rağmen aşağıda çalışmanın ana unsurlarını oluşturan inovasyon türleri üzerinde durulmaktadır.

\section{1.Ürün İnovasyonları}

Ürün, bir ihtiyaç ya da beklentiyi karşılamak için pazara sunulan bir nesnedir. Başka bir ifadeyle bir işletmenin ihtiyaç giderici sunumudur. Pazarlanan ürünler olarak fiziksel 
mallar, hizmetler, tecrübeler, mekânlar, kişiler organizasyonlar, bilgiler ve fikirler sayılmaktadır (İraz, 2005: 102).

Ürün inovasyonu belirli bir müşteri kitlesinin talebini karşılamak için yeni bir ürün veya var olan ürüne yeni özellikler ekleyerek pazara sürülmesinde ortaya çıar. Ürün inovasyonları teknolojik inovasyon içerebilir ama ihtiyacı yoktur. Bu ürünler hizmet ve mal içerdiğinden çok açıktır. Ürün inovasyonunun temel amacı işletmeye geçici de olsa tekel pozisyonu sağlayacak yeni ürün veya ürün çeşitleri ortaya koymaktır; bu da ona marjinal maliyetleri üzerinde bir fiyat koyma özgürlüğü verir (Tavassoli ve Karlsson, 2015: 1889). Müşteri temelli talepleri karşılama maksadı ile tanıtılan yeni ürünler veya hizmetler ürün inovasyonu olarak bilinir (Birasnav ve diğerleri, 2013: 66).

İnovasyonu başarıyla benimseyen küçük işletmeler hayatta kalma ve büyüme şanslarını arttırır. İnovasyon hızlı büyüyen KOBİ’ler için hayati öneme sahiptir. Ürün inovasyonları yürüten KOBİ'ler olmayanlara kıyasla daha yüksek büyüme oranları elde edecektir (Subrahmanya,2015: 26).

\subsection{Süreç İnovasyonu}

İşletmelerde belirli mal ve hizmetleri üretebilmek için yapılması gereken bir dizi iş ve faaliyet topluluğuna süreç kavramı adı verilmektedir. Ayrıca süreç kavramı farklı türde girdilerden müşteri için değer oluşturacak bir çıktının meydana getirilmesi için yapılan faaliyetlerin toplamı olarak da tanımlanır (Marangoz,2012: 53).

Süreç inovasyonu, var olan iş ve faaliyetler bütününün gözden geçirilerek yeniden yapılandırılmasıdır. Yeniden yapılanma süreci sonucunda müşteri tatmininin artması beklenmektedir; müşteri tatmini artmıyorsa süreç yenileme etkili olmamıştır. Çünkü süreç yenilemede amaç, müşterilerin değer verdiği iş ve faaliyetleri daha da geliştirmek olmalıdır. Böylece müşteri tatmini ve beklentileri daha iyi karşılanacak işletme de rekabet üstünlüğü sağlamış olacaktır (Ülgen ve Mirze, 2004: 390).İşletmelerin rekabet avantajı sağlaması, diğer işletmelerin yapamadığı ürünleri daha farklı yöntemlerle yapabilmesiyle mümkün olacaktır (Aslan, 2014: 19).

Süreç inovasyonu, iki şekilde sınıflandırılır. İlki süreç teknolojisinin dünyaya yeniliğibelirli bir süreç teknolojisi pazar tarafından hangi derecede biliniyor. Diğerisüreç teknolojisinin işletmeye yeniliği; belirli bir süreç teknolojisi belirli bir işletmenin üretim sistemine hangi derecede yerleşmiştir. Süreç inovasyonu üretim süreci maliyetlerini düşürmeyi ve ürün hacmini artırmayı amaçlar (Birasnav ve diğerleri,2013: 66).

\subsection{Organizasyonel İnovasyon}

İşletmelerin iş yöntemlerini değiştirmesi ve geliştirmesi, farklılaştırması ve yenilemesi organizasyonel inovasyon olarak tanımlanır. Organizasyonel inovasyonla işletmede var olan yöntemlerin, işletme şartlarına uyumlu hale getirilmesi söz konusudur. Bu inovasyon 
çeşidi ile maliyetleri düşürmek ve verimliliği artırmak temel amaçtır (Keskin,2012: 20).

Organizasyonel inovasyon ile işletmelerin iş performansı ilişkisini belirlemeye yönelik yapılan birçok araştırma bulunmaktadır. İlgili araştırma bulguları; organizasyonel inovasyonun uzun dönemli rekabet üstünlüğ̈̈ sağlamadaki önemini göstermektedir. $\mathrm{Bu}$ inovasyon, rekabet üstünlügü sağlamada iki ana işlevi yerine getirmektedir. Birinci ana işlev, bu inovasyonun teknik seviyedeki ürün ve süreç inovasyonları için ön koşul olmasıdır. İşletme bu inovasyon çeşidinde başarılı değilse, sürdürülebilir bir ürün inovasyonu oluşturmaz. İkinci ana işlevi ise, bu inovasyonun rekabette üstünlügü sağlama aracı olmasıdır. Organizasyonel inovasyon ile taklit edilmesi mümkün olmayan, organizasyonun kendine özgü ve değerli bir öz yetkinliği oluşturulmaktadır (Burmaoğlu ve Şeşen, 2011:3).

Organizasyonel inovasyonlar etkinlik, üretkenlik karlılığı, esneklik ve yaratıcılığı arttırmayı hedefleyen, işletmenin rutinindeki değişiklikleri içeren inovasyonlardır. Bu inovasyonun örnekleri aşağıda sıralanmıştır (Tavassoli ve Karlsson, 2015: 1890).

$\checkmark$ Yeni stratejilerin tanitılması ve uygulamaya konulması,

$\checkmark$ İşçiler arasında bilgi yayılımını, depolamayı, kodlamayı, paylaşmayı, adaptasyonu, araştırma becerilerini arttıran bilgi yönetim sistemlerinin tanıtılması,

$\checkmark$ Yeni yönetimsel ve kontrol sistemleri ve süreçlerinin tanıtılması,

$\checkmark$ Takım çalışması ve dağıtılmış karar vermeyi de içeren teşvik edici yapısıyla birlikte yeni dâhili yapının tanıtımı,

$\checkmark$ Tedarikçiler, müşteriler, müttefikler, ortaklar, taşeronlar, dışkaynaklar ve offshoring ile dikey işbirliğini içeren diğer işletmeler ve /veya kamu kuruluşlarıyla harici şebeke ilişkilerinin tanıtılması,

$\checkmark$ İşletme içi kilit pozisyonlara yeni personel alımı.

\subsection{Pazarlama İnovasyonu}

Pazarlama inovasyonu, yüksek performans yolunda rekabet avantajında önemli bir kaynaktır. Schumpeter, inovasyonun işletmelerin varlık sermayelerini sürdürmede yardımcı olduğunu, öbür türlü mükemmel rekabete doğru acımasızca eğilimi olan ekonomik dinamiklerin altında eriyeceğini öne süren ilk kişidir (Naidoo,2010: 1313). Deneysel kanıtlar pazarlama inovasyonunun rekabet avantajı elde etmede ve geliştirmede yararlı olduğunu gösterir, en azından maliyetleri düşürmede ve farklılaşmada etkilidir (Tavassoli ve Karlsson, 2015: 1889).

Ürün, hizmetlerde ve ambalajda farklı ve yeni bir tasarım ve de müşteri ilişkileri 
yöntemlerinde farklılıklar pazarlama inovasyonuyla gerçekleştirilir. Pazarlama inovasyonuyla amaç yeni pazarlar bulmak, ürünü farklı bir şekilde konumlandırmak, satışları artırmak, müşterilerin ihtiyaç ve beklentilerini karşılamaktır. Örnek olarak dünyada www.amazon.com ve ülkemizde ise www.yemeksepeti.com verilebilir (Keskin,2012: 18-20). Özellikle anaokulu ve kreşler hedef alınarak vitranın çocuklar için geliştirmiş olduğu çocuk ergonomisi düşünülerek tasarlanmış “junior banyo” ürünleri pazarlama inovasyonuna örnek gösterilebilir (Elçi,2006: 12-13).

Ürün veya hizmet gelişimi inovasyonun en bilinen türü olabilir ama diğer türler süreç, pazarlama, lojistik ve işletme inovasyon modellerini içerir. İnternetteki gelişmeler işletmelerin pazarlama kanallarının web sitelerini içermesine izin verir ki bu pazarlama inovasyonunu birinci / en önemli örneğidir. Müşteriler, distribütörler, ve tedarikçilerle birlikte çalışmaya izin veren stratejik ortaklık işletme modellerinde inovasyonu temsil eder (Robinson ve Stubberud,2012: 54).

\section{KOBİ'LERDE İNOVASYONUN ÖNEMİ VE İNOVASYON GEREKSINIIMİ}

İnovasyonun işsizlik, refah oluşumu ve ulusal ve uluslararası seviyede ekonomik büyüme için önemi, literatürde neden bu kadar dikkat çektiğini açıklamaktadır. Yoğun global rekabetin, kısalan ürün yaşamı döngülerinin ve hızla değişen tüketici zevklerinin olduğu bir çağda inovasyon önemlidir. Madrid- Guijjaro işletmelerin hayatta kalmak, rekabetçi olmak ve büyümek amacıyla inovasyon yapmak için teknolojik kapasitelerinin avantajlarını sonuna kadar kullanmaları gerektiğini önermiştir. Madrid- Guijjaro; inovasyon ve rekabetçilik arasındaki yakın ilişkileri hem mikro hem de makro seviyelerde vurgulamışlardır (Kotey ve Sorensen, 2014: 407).

KOBI'ler istihdam yaratma, ekonomik büyüme ve gelişmekte olan ekonomilerin ve gelişmiş ekonomilerin ekonomik dinamikleri açısından önemli bir unsurdur. KOBİlerin bu katkıları yapabildikleri en önemli araçlardan biri, inovasyonu gerçekleştirme kabiliyetidir. Farklı büyüklükteki işletmeler arasında KOBİ'ler genellikle daha esnektir kendilerini daha iyi uyarlar, müşterilerine yakın olurlar ve daha yeni fikirler geliştirip uygulamaya koyulurlar. Basit nitelikteki organizasyon yapısı, düşük risk algılamaları, aslında bu özelliklerin inovatif olmalarını kolaylaştıran temel özelliklerdir. KOBİlerin inovasyon yapma kabiliyeti önem kazanmaktadır. Çünkü inovasyon ulusların bölgelerin işletmelerin rekabetçiliğinde faktör olarak yaygın kabul edilmektedir. Teknolojik inovasyon, bireysel girişimlerin mikro düzeyde büyümesini teșvik ve makro düzeyde sanayi büyümesine yeni bir boyut kazandırma potansiyeline sahiptir. Farklı büyüklükteki işletmeler arasında, yeni kurulan işletmeler, endüstriyel ve çevre ekonomileri dâhil olmak üzere KOBİler gerçekleşmemiş inovasyon potansiyeline sahiptir (Subrahmanya,2015: 26-27).

KOBİ’lerin esnek yapıları inovasyon aktiviteleri için büyük şirketlerden daha fazla avantaj sağlar. Teknoloji, üretim metotları ve pazarlama gibi inovasyonlara daha kolay uyum sağlayan KOBI'ler kolaylıkla, Ar-Ge sonucu ortaya çıkan ürünü ticari hale getirebilir. İnovasyon temelli stratejiler önemli katkılar sağlar, KOBİ’ler için rekabetçiliği artırır, 
koruma ve sürdürülebilirliği garanti eder (Bozkurt ve Kalkan,2014: 190).

KOBİ'lerin performansına direkt etkisinin yanında inovasyon süreci boyunca öğrenmek, bilgiyi uygulama, asimile etme ve belirleme olarak tanımlanan emici kapasiteyi meydana getirir. İnovatif KOBİler tarafından geliştirilen emici kapasite sonuçta rekabet avantajı demektir. İnovasyonun faydaları; ekonomiyi öğrenme, ölçek ve kapsam ekonomisi ileriki inovasyonlar da avantaj ve standartları belirleme yetisini içerir (Rosenbuusch,2011: 444). İnovasyon ve profesyonellik arasındaki ilişki aile işletmelerinin inovatif kapasitelerini etkileyebilecek kritik ama tartışmalı bir konudur. Profesyonellik mevcut durumun ötesine geçmek için bağllık, özgüven ve sınır-kapsam aktivitelerini arttırır ve inovasyon da üstün rekabetin önemli bir kaynağıdır. Şu anki işletme ortamının karmaşıklığı ve dinamikliği rekabet avantajına sahip olmada önemli olan her iki kilit faktörde derin bilgiye sahip olmayı gerektirir (Soto,J.D,2016: 332-333).

\section{KOBI''LERDE İNOVASYON STRATEJILERI}

Streckere göre; inovasyon stratejisi inovasyon aktivitesine bağlı olarak işletmenin yaptığı stratejik seçimlerin toplamını ifade eder.Wei ve Wang inovasyon stratejisinin işletmenin organizasyon içinde inovasyonu teşvik ve değerlemesini yansıttığını söyler. Dodgson inovasyon stratejisinin, inovasyon için işletmenin amaçlarını karşılamakta kaynakların nasıl kullanılacağını ve böylelikle rekabetçi avantaj sağlamak ve değer katmaya rehberlik edeceği sonucuna varmıştır. İnovasyon stratejisi işletmelerin kurumsal amaçlara en iyi uyan inovasyon türüne karar vermesine yardımcı olur (Sattayaraksa ve Sakun, 2015: 108109).

KOBİ'ler rekabetçi ortamda varlıklarını sürdürmek ve durumlarını korumak için inovasyona önem vermelidir. İnovasyon stratejileri ile KOBİ'lerin küresel alanda rekabet avantajı sağlamaları mümkündür. KOBI'lerin bazıları tamamen inovatif stratejiler belirlemektedir. Diğer taraftan bazı KOBİ'lerde, büyük işletmelerin tercih etmedikleri alanlarda yenilik aramaktadır. Böylece yapılan, yeniliklerin patentleri üzerinden gelir sağlamaktadır. Bunun gerçekleşmesi için pazarı ve teknolojiyi ciddi bir şekilde izlemelidirler. KOBİ'ler teknik düşünceleri ve uygulamaları ilk kez kullanarak, büyük işletmelerin desteklerini alabilirler (Aksoy ve Demirel,2008: 396-397). KOBİ'lerde inovasyon stratejileri saldırgan, savunmaya yönelik, taklitçi, bağımlı, geleneksel ve farklılaştırma stratejileri olarak sıralanabilir (Deniz,2011: 152).

\subsection{Saldırgan İnovasyon Stratejileri}

Yeni bir ürünü veya yeni bir üretim sürecini rakip işletmelerden daha önce geliştirip pazara sunarak teknik alanda ve pazarda önderliği ele geçirmek bu stratejinin temel amacını oluşturmaktadır. Saldırgan stratejiyi uygulamak isteyen işletmelerin yüksek gelir beklentisi ile birlikte yüksek risk olasılığı da bulunmaktadır. Dolayısıyla başarısızlık kaçınılmaz olabilir. Bu nedenle, bu stratejiyi uygulamak isteyen işletmelerde Ar- $\mathrm{Ge}$ bölümüne büyük görev düşmektedir (K1liç,2011: 118). 


\subsection{Savunmaci İnovasyon Stratejileri}

Savunmacı inovasyon stratejisini uygulayan işletmeler, teknoloji üretme konusunda öncü ve pazarlara ilk giren olma amacını taşımazlar. Fakat teknolojik gelişmelerin de gerisinde kalmak istemezler. Bu stratejiyi uygulayan işletmeler yüksek Ar-Ge maliyetlerinden ve radikal yeniliklerden oluşan riskten kaçınmak isterler. Bu stratejiyi tercih eden işletme teknolojik yenilik yapmaktansa bunun yerine var olan teknolojide iyileştirmeler yapmayı hedefleyebilir. Diğer bir deyişle işletme radikal bir yenilik yerine tedrici bir yeniliği tercih etmektedir. Savunmacı inovasyon stratejisini benimseyen işletmeler, iyileștirilmiş ürünlerini sınırlı sayıdaki pazar bölümlerine yönlendirerek, buralarda etkili ve verimli olmak isterler. Bunun için daha fazla çaba gösterirler (Deniz,2011: 155).

\subsection{Taklitçi İnovasyon Stratejileri}

$\mathrm{Bu}$ stratejiyi izleyen işletmeler genelde lider işletmeyi takip etmektedir. Ayrıca düşük işgücü, malzeme, enerji ve yatırım maliyetleriyle çalışmayı tercih etmektedirler. Ar-Ge'ye fazla kaynak ayırmak istemezler. Bu stratejiyi benimseyen işletmeler pazarda hakim olan teknolojiye sahip olamadıklarından maliyet üstünlügü ile rekabet etmeye çalışmaktadır (Güleş ve Bülbül, 2004: 176).

\subsection{Bağımlı İnovasyon Stratejileri}

Bu stratejide işletmeler, teknolojik yenilik açısından güçlü bir işletmenin uydusu ve alt kuruluşu gibi çalışmaktadır. Bağımlı işletmeler, genellikle ürün tasarımında ve Ar-Ge faaliyetlerinde bütünüyle büyük işletmeye bağlı olan sermaye yoğun işletmelerdir. Tam bağımlı strateji benimseyen işletmeler, büyük ölçekli ve teknolojik bakımdan güçlü bir işletmenin bir departmanı gibi faaliyet göstermektedir (Kılıç,2011: 120).

\subsection{Geleneksel İnovasyon Stratejileri}

Teknolojileri genellikle mesleki yetenek ve becerilere dayanmaktadır. Pazarda değişim talebi olmaması ve rekabetin değişime zorlamaması durumunda değişikliğe gidilmesi söz konusu değildir. Yapılan değişiklikler ise teknoloji boyutuyla ilgili olmayıp daha ziyade "moda" olarak adlandırılabilecek tasarıma yönelik yeniliklerdir. Bu stratejiyi izleyen işletmelerin, teknolojik yeniliklerin yüksek olduğu ve teknoloji bağımlı endüstrilerde yaşamaları oldukça güçtür. Diğer işletmelerin yaptıkları yeniliklerin etkisiyle endüstrilerin de zamanla dışlanmaları söz konusudur (Tokmak,2008: 85).

\subsection{Firsatları İzleme Stratejisi}

Bustratejide rakibin zayıfyönüve pazarın keşfedilmemiş yönleribulunmaya çalışılmaktadır. Bu stratejiyi izleyen işletmeler, dışa dönüktür. Ayrıca sürekli olarak yeni pazar fırsatları araştırmaktadırlar. Bu stratejiyi benimseyen işletmelerin genelde inovasyona açık işletmeler olduğu söylenebilir. Bu işletmelerde Ar-Ge faaliyetleri önemlidir. Hızlı değişen 
pazarlarda lider işletmenin görmediği ya da boş bıraktığı fırsatlardan yararlanmaktadırlar. Bunu başarırken rakiple karşı karşıya gelmezler. Rakipleri kadar etkili olmasalar da sürekli rakiplerine karşılık verebilecek yenilikler yapmaları mümkündür. İşletmelerin bu stratejiyi başarı ile uygulayabilmesi için güçlü bir iletişim ağına sahip olması gerekmektedir. Ayrıca pazardaki fırsatları ilk önce görmesi, potansiyeli yüksek yeni fikirleri ilkfark eden olması ve büyük rakipler tarafından göz ardı edilen geniş pazarlardaki fırsatları değerlendirmesi önem arz etmektedir. Bu stratejide girişimcilik yeteneği yüksek olan işletmelerin başarı şansı yüksektir (Tokmak,2008: 86).

\section{KOBI'LERDE İNOVASYON ENGELLERİ}

KOBİ'ler de inovasyon çalışmaları inovasyonu engelleyen veya katılan faktörlere ve başarılı bir inovasyon karakteristiğine odaklanmaktadır. Örneğin; Damanpour (1991) inovasyon ve aşağıdaki belirleyiciler arasında pozitif ilişki bulmuştur. Dış-iç iletişim, kaynaklar, yönetimsel yoğunluk, teknik bilgi kaynakları, değişime karşı yönetimsel tavır, profesyonellik, fonksiyonel farklılık ve uzmanlıktır. Resmileştirme, yönetimsel imtiyaz ve dikey farklılık gibi bazı belirleyicilerin belirli bir ilişkisi olmadığını bulduğu gibi, inovasyon ve merkezcilik arasında negatif ilişki bulmuştur (Laforet,2013: 490-491).

Sanayileşmiş ülkelerde bile KOBİ'lerin büyük işletmelerden daha fazla inovasyon engelleriyle yüzleşmesi beklenir. KOBİler görece daha az uzmanlık veya iç kaynaklara sahip olduklarından, inovasyonun interaktif karakteri büyük işletmelerde daha yoğun hale gelir. $\mathrm{Bu}$, engellere daha fazla önem verilmesinin sebeplerinden biridir. KOBİ'ler inovasyon engellerini belirledikleri, etkilerini ve bunları elemek için çalıştıkları takdirde inovasyonun doğal akışı yeniden kurulacak ve sürdürülecektir. İnovasyon otomatik ve kendiliğinden bir süreç olmadığından girişimcilerin motivasyon, efor ve ilerlemek için riskleri kabullenmelerine ihtiyaç duyar. Girişimciler inovatif aktiviteleri boyunca çeşitli engellerle karşılaşırlar. Hadjimanolis, inovasyon engellerini iki şekilde gruplandırmıştır; içsel engeller ve dışsal engeller. Dişsal engeller tedarik, talep ve çevresel olarak gruplandırılmıştır. Tedarik engelleri, teknolojik bilgi, finansal ve kayıp materyal olarak çeşitlendirilir. Talep engelleri, tüketici ihtiyaçları, inovasyonun risk olarak görülmesi, ulusal ve uluslararası pazar sınırlarını içerir. Çevresel engellerin değişik hükümet kanunları, rekabet ölçümleri ve kanunlar olduğu söylenebilir. İçsel engellerin bir kısmı işletmenin yetersiz kaynaklarından ötürüdür. Finansal gücün azlığı, teknolojik uzmanlığın yetersizliği, yönetim, kültür vb. içsel engellere örnek verilebilir. İçsel engellerin diğer kısmı sistemin yetersizliğindendir. Eski muhasebe sistemleri örnek olarak verilebilir. İçsel engellerin diğer bir kısmı insan kaynaklarının yetersizliğindendir. Riske karşı yönetimin tavrı, çalışanların yeniliğe direnmesi örnek olarak verilebilir. Piatner, engelleri işletmeye karşı dıştan(tedarik, talep, çevresel) ve işletmeye karşı içten (kaynak bağıntıll, kültür ve sistemler bağıntılı, insan doğası bağıntılı) olarak farklılaştırmıştır. Tedarik engelleri, teknolojik bilgi, ham maddeler ve finansmanın sağlanması zorluğunu içerir. Talep engelleri tüketici ihtiyaçları, inovasyonun riskleri algılama biçimleri ve içsel, dişsal pazar sınırlamalarıdır. Çevresel olanlar, farklı hükümet yönetmeliklerini, güvensizlik ölçümlerini ve politika davranışlarını içerir. Kaynak bağıntılı olanlar, içsel fonların, 
teknolojik uzmanlığın veya zaman yönetimi eksikliği; kültür ve sistem bağıntılı olanlar çağdışı muhasebe sistemleri; insan doğası bağıntılı olanlar bazı yönetimin riske karşı tavrı veya çalışanların yeniliğe karşı direnci olarak tanımlanabilir (Kalkan ve diğerleri, 2012: 104-106).

\section{6. ÇANAKKALE ILINNDE FAALIYYT GÖSTEREN KOBİLERE YÖNELIKK BİR ARAŞTIRMA}

Çanakkale sınırları içerisinde yer alan KOBİlere yönelik araștırma sonuçları değerlendirilecektir. Çanakkale'de faaliyette bulunan işletmelerinin büyük çoğunluğu KOBİ statüsündeki işletmeler oluşmaktadır. Ayrıca il sınırları içinde sanayi işletmelerinin büyük bir kısmını KOBİ’ler oluşturmaktadır.

\subsection{Araştırmanın Amacı}

KOBİlerde inovasyon türleri ve inovasyon uygulamalarını etkileyen faktörler belirlenmeye çalışılacaktır. İnovasyon uygulamaları, KOBİlerde işletme içi ve işletme dişı engeller olarak ayrılmakta ve her iki engelin olumsuz etkileri tespit edilecektir. Diğer taraftan işletmelerin Ar-Ge'ye ayırdıkları pay, işletmelerin içinde bulundukları sektörün yapısı ve faaliyet alanları inovasyon etkenleri olarak ele alınmaktadır. KOBİlerde inovasyon türleri ile inovasyon etkenleri arasındaki ilişki üzerinde durulmaktadır.

\subsection{Evren ve Örneklem}

Çanakkale il merkezi ve ilçeleri, araştırmanın uygulanacağı bölge olarak belirlenmiştir. Örneklem bölgesi belirlendikten sonra örneklem büyüklügünün belirlenmesi amacıyla; Çanakkale Ticaret ve Sanayi Odası, Çanakkale KOSGEB İl Müdürlüğü, Çanakkale Sanayicileri ve İşadamları Derneği ve Çanakkale Tarım İl Müdürlüğü yetkilileriyle görüşülmüştür. Çalışan sayısı 1-9 arasında olan mikro ölçekli işletmeler ve çalışan sayısı 250 üzeri olan işletmeler çalışma kapsamına alınmamıştır. TUİK Balıkesir Bölge Müdürlüğü ve Çanakkale KOSGEB İl Müdürlüğünden alınan verilere göre; Çanakkale de faaliyette bulunan ve çalışan sayısı 10-49 olan 749işletme, çalışan sayısı 50-249 olan 50 işletme bulunmaktadır.

Yüz yüze görüşme tekniği kullanılarak, anket uygulaması gerçekleştirilmiştir. Toplam 132 anket araştırmada kullanılmıştır. Uygulama için tercih edilen işletmelerin bazıları katılımı istememiştir. Bazı anketler ise analizler için uygun şartları taşımamaktadır.

\subsection{Araştırmanın Yöntemi}

Araştırma yöntemi olarak anket uygulaması gerçekleştirilmiş ve uygulamaya yönelik anket formun dört bölümden oluşmaktadır. Anket formunun birinci bölümünde, işletme temsilcilerinin demografik özellikleriyle, işletme bilgilerine yönelik sorular bulunmaktadır. Demografik özelliklere yönelik; cinsiyet, yaş, eğitim durumu, işletmedeki görev durumu 
ve çalışma süresi hakkında sorular bulunmaktadır. Ayrıca bu bölümde; işletmenin yasal statüsü, faaliyet süresi, faaliyette bulunduğu sektör, istihdam edilen çalışan sayısı, Ar-Ge payları, inovasyon stratejilerini belirlemeye yönelik sorular yer almaktadır.

Anket formunun İkinci ve üçüncü bölümde 5’li Likert ölçeği soruları bulunmaktadır. İnovasyon türlerini belirlemek amaciyla 20 soru sorulmuştur. Bu bölümde işletmelerin inovasyona bakış açısı ve hangi inovasyon türlerini benimsedikleri ve uygulamaya geçirdiklerine yönelik sorular yer almaktadır.5'li likert tipi soruların oluşturulmasında (Günay, 2007: 99-102) ve (Kılıç,R., 2011: 239-242) tarafından uygulanan anket formlarından da yararlanılmıştır.

Anket formunun üçüncü bölümünde inovasyon uygulamalarını engelleyen işletme içi ve işletme dışı faktörleri belirlemek amacıyla 43 soru sorulmuştur. Bu bölümde işletmenin inovasyon konusundaki düşünce ve tutumları tespit edilmektedir. 5'li likert tipi soruların oluşturulmasında (Günay, 2007: 99-102) ve (Kılıç,R. 2011: 239-242) tarafından uygulanan anket formlarından da yararlanılmıştır.

Araştırma kapsamındaki regresyon modelleri SPSS 20.0 istatistik paket programı ile analiz edilmiştir. Araştırmada kullanılan ölçeklerin güvenilirliğini belirlemek için, ölçeklerin içsel tutarlılıkları ölçülmüştür. Analiz kapsamında güvenilirlik katsayıları rakamları, çalışmada kullanılan ölçeklerin güvenilir olduğunu göstermektedir. Demografik verilerin analiz edilmesinde frekans analizleri uygulanmıştır. Hipotezlerin test edilmesi amacıyla Korelasyon Analizi, Çoklu Regresyon Analizi ve Anova analizi, T-testi uygulanmıştır. Korelasyon analizi için araştırma değişkenlerine ait Pearson Korelasyon katsayıları, ortalama, standart sapma ve korelasyon değerleri hesaplanmıştır. Çalışma kapsamında toplanan verilerin faktör analizi için uygunluğunu anlamak için Kaiser-Meyer-Olkin örneklem yeterliliği değerine bakılmıştır. Ayrıca, KOBİler tarafından uygulanan inovasyon türlerini ve inovasyon uygulamalarında karşılaşılan engelleri tespit etmek amacıyla 5’li likert tipi sorulara faktör analizi uygulanmıştır.

\subsection{Araştırmanın Sinırlılıkları}

Çanakkale ili ve ilçelerinde faaliyette bulunan KOBİ’ler araştırma kapsamını oluşturmaktadır. Veri toplama yöntemi olarak anket formları uygulanmıştır. Anket formlarına yönelik saha çalışmaları yaklaşık iki yıl (2016-2017) sürmüştür. Araştırmada anketler çalışan sayısı 10-250 arasında olan KOBİlere uygulanmıştır. Mikro ölçekli işletmeler değerlendirme kapsamının dışında bırakılmıştır. Araştırma yöntemi ve ankete katılan işletme sahibi ve yöneticilerinden kaynaklanan eksiklikler araştırmanın sınırlılıkları içerisinde yer almaktadır. Ayrıca araştırma ile belirlenen sonuçların Türkiye'de faaliyette bulunan KOBİ’lerin tümünü kapsayacağı iddia edilemez.

Araştırma kapsamına dâhil işletmeler arasında sektörel ayrım söz konusu değildir. Araştırmada tercih edilen KOBİ'lerin yapısı ve araştırma kısıtları sonuçları etkilemektedir. Bu bağlamda içşel ve dışsal inovasyon engellerinin belirlenmesine yönelik çıkan sonuçlar 
o anki durumla ilgilidir.

\subsection{Araştırmanın Modeli}

Modelde gösterildiği üzere, demografik belirleyicilerle inovasyon türleri arasındaki ilişkiler incelenmiştir. Modelde vurgulanan bir diğer konu ise inovasyon türleri ile inovasyon engelleri arasındaki ilişkidir. Bu durum işletmelerin inovasyon tutumlarının belirlenmesi açısından önemlidir. İnovasyon engelleri ise iki boyutta incelenmiştir. Bunlar içsel inovasyon engelleri ve dişsal inovasyon engellerdir. Modelde vurgulanan son konu ise inovasyon türleri ile inovasyon stratejileri arasındaki ilişkiyi belirlemeye yöneliktir.

\section{Şekil 1. Araştırma Modeli}

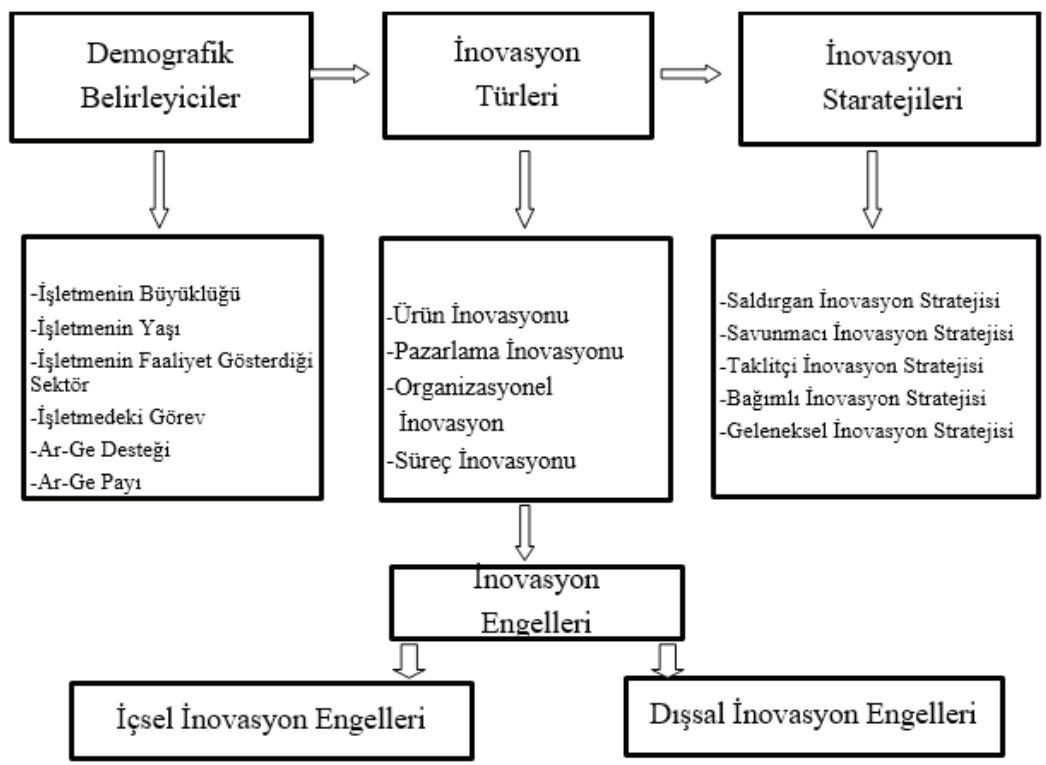

\subsection{Araştırmanın Hipotezleri}

Araştırmanın hipotezleri demografik belirleyicileri ile inovasyon türleri, inovasyon türleriyle inovasyon engelleri ve inovasyon stratejileri arasındaki ilişkiyi belirlemeye yöneliktir. Aşağıda hipotezler gösterilmektedir. Alt hipotezlerde ise ürün, süreç, organizasyonel ve pazarlama inovasyonlarıyla ilişki durumları irdelenmektedir.

H1:KOBİ’lerin almış olduğu Ar-Ge desteği ile inovasyon türleri arasında pozitif ve anlamlı bir ilişki vardır.

H2: KOBİlerin bütçeden ayırdıkları Ar-Ge payı ile inovasyon türleri arasında pozitif ve anlamlı bir ilişki vardır. 
H3: KOBİ’lerin inovasyon stratejileri ile inovasyon türleri arasında pozitif ve anlamlı bir ilișki vardır.

H4: KOBİ’lerin büyüklügü ile inovasyon türleri arasında pozitif ve anlamlı bir ilişki vardir.

H5: KOBİ’lerin yaşı ile inovasyon türleri arasında pozitif ve anlamlı bir ilişki vardır.

H6: KOBI’lerin faaliyet gösterdiği sektör ile inovasyon türleri arasında pozitif ve anlamlı bir ilişki vardır.

H7: İşletmedeki görev ile inovasyon türleri arasında pozitif ve anlamlı bir ilişki vardır.

H8: KOBİ’lerdeki içsel engeller ile inovasyon türleri arasında pozitif ve anlamlı bir ilişki vardır.

H9: KOBİ'lerdeki dışsal engeller ile inovasyon türleri arasında pozitif ve anlamlı bir ilişki vardır.

\subsection{Araştırma Bulguları}

\subsubsection{Demografik Analizler}

Ankete katılan çalışanlara ilişkin temel karakteristik ve demografik veriler ile ankete dâhil olan işletmelere ilişkin istatistiki veriler ile ilgili tablolar aşağıda verilmiştir.

\section{Araștırmaya Katılan Çalışanlara Ait Temel Karakteristik ve Demografik Veriler}

Tablo 1'de görüldüğü gibi araştırmaya katılanların 100'ü erkek, 32'si kadınlardan oluşmaktadır. Bunların toplam içerisindeki yüzdelik dağılımları ise, sırasıyla yaklaşık $\% 76$ ve \% 24'tür. Kadın katılımcıların sayısının az olması, sektörde çalışanların genelde erkek olmalarından kaynaklanabileceği düşünülebilir (Tablo 1).

\section{Tablo 1. Ankete Katılanların Cinsiyeti}

\begin{tabular}{|l|c|c|}
\hline Cinsiyet & Sıklık & Yüzde (\%) \\
\hline Erkek & 100 & 75,8 \\
\hline Kadın & 32 & 24,2 \\
\hline Toplam & $\mathbf{1 3 2}$ & $\mathbf{1 0 0}$ \\
\hline
\end{tabular}

Tablo 2'de görüldüğü üzere ankete dâhil olan katılımcıların sadece \% 4,5'i ilköğretim, \% 28'i lise, \% 15,2'si önlisans, \% 40,2'si üniversite ve \% 16sı ise lisansüstü eğitim düzeyine sahiptir. $\mathrm{Bu}$ sonuçlar bize, ankete katılanların çoğunluğunun eğitim düzeylerinin üniversite seviyesinde olduğunu göstermektedir (Tablo 2). 
Tablo 2. Ankete Katılanların Eğitim Durumu

\begin{tabular}{|l|c|c|}
\hline Eğitim Durumu & Sıklık & Yüzde (\%) \\
\hline İlköğretim & 6 & 4,5 \\
\hline Lise & 37 & 28,0 \\
\hline Önlisans & 20 & 15,2 \\
\hline Lisans & 53 & 40,2 \\
\hline Lisansüstü & 16 & 12,1 \\
\hline Toplam & $\mathbf{1 3 2}$ & $\mathbf{1 0 0}$ \\
\hline
\end{tabular}

Ankete katılanların işletmedeki görevlerine bakıldığında 69'unun işletme sahibi veya ortağ1, 29'nun üst kademe yönetici, 34'ünün orta kademe yöneticilerden oluştuğu görülmektedir (Tablo 3).

\section{Tablo3. Ankete Katılanların İşletmedeki Görevleri}

\begin{tabular}{|l|c|c|}
\hline İşletmedeki Görevler & Sıklık & Yüzde (\%) \\
\hline İşletme Sahibi / Ortağı & 69 & 52,3 \\
\hline Üst Kademe Yönetici (Genel Müdür / Müdür Yardımcısı gibi) & 29 & 22,0 \\
\hline $\begin{array}{l}\text { Orta Kademe Yönetici (Muhasebe, Pazarlama Müdürü / Müdür Yardım- } \\
\text { cısı gibi) }\end{array}$ & 34 & 25,8 \\
\hline Toplam & $\mathbf{1 3 2}$ & $\mathbf{1 0 0}$ \\
\hline
\end{tabular}

Ankete katılanların yaklaşık üçte birinin işletmedeki çalışma süresinin 5 yıldan az olduğu, yüzde 23,5’inin ise 6 ile 10 yıl arasında firmada çalışmakta olduğu görülmektedir. Yaklaşık yarısının da 10 yıldan daha fazla süredir firmada bulunduğu gözlenmiştir (Tablo 4).

\section{Tablo 4. Ankete Katılanların İşletmedeki Çalışma Süresi}

\begin{tabular}{|l|c|c|}
\hline İşletmedeki Çalışma Süresi & Sılklık & Yüzde (\%) \\
\hline $0-5$ yıl & 47 & 35,6 \\
\hline $6-10$ yıl & 31 & 23,5 \\
\hline $11-15$ yıl & 19 & 14,4 \\
\hline $16-20$ yıl & 18 & 13,6 \\
\hline $21-25$ yıl & 10 & 7,6 \\
\hline 25 ve üzeri yıl & 7 & 5,3 \\
\hline Toplam & $\mathbf{1 3 2}$ & $\mathbf{1 0 0}$ \\
\hline
\end{tabular}

Araştırmaya Katılan İşletmelere Ait Tanımlayıcı İstatistikler

Katılımcılara işletmelerinin yasal statüleri sorulmuş ve işletmelerin büyük çoğunluğunun 
(\% 55,3) limited şirket olduğu saptanmıştır. Şirketlerden 31 tanesi ise tek şahıs işletmesidir. Firmalardan sadece bir tanesi kamu işletmesi ve yine sadece yedi tanesinin yasal statüsü ortaklıktır (Tablo 5).

\section{Tablo 5. İșletmelerinin Yasal Statüleri}

\begin{tabular}{|l|c|c|}
\hline Yasal Statüler & Sılklık & Yüzde (\%) \\
\hline Tek Şahı́ İşletmesi & 31 & 23,5 \\
\hline Ortaklık & 7 & 5,3 \\
\hline Limited Şirket & 73 & 55,3 \\
\hline Anonim Şirket & 20 & 15,2 \\
\hline Kamu & 1 &, 8 \\
\hline Toplam & $\mathbf{1 3 2}$ & $\mathbf{1 0 0}$ \\
\hline
\end{tabular}

Ankete katılanların çalıştığı işletmelerin büyüklüklerini belirlemek amacıyla işletmelerin toplam çalışan sayıları sorulmuştur. İşletmelerin 62'inde çalışan sayısının 25 'ten az olduğu, 35 tanesinde 26-50 arasında ve 35 tanesinde 50'den fazla olduğu gözlenmektedir (Tablo 6).

\section{Tablo 6. Firmanın Toplam Çalışan Sayısı}

\begin{tabular}{|l|c|c|}
\hline Firmanın toplam çalışan sayısı & Sıklık & Yüzde (\%) \\
\hline $10-25$ arası & 62 & 47,0 \\
\hline $26-50$ arası & 35 & 26,5 \\
\hline $51-100$ arası & 17 & 12,9 \\
\hline $101-249$ arası & 18 & 13,6 \\
\hline Toplam & $\mathbf{1 3 2}$ & $\mathbf{1 0 0}$ \\
\hline
\end{tabular}

İşletmelerin geçmişine bakıldığında 21'inin 5 yıldan az, 22'sinin 6 ile 10 yıl arasında, 21 'inin 11 ile 20 yıl arasında ve 44 'ünün ise 21 yıldan fazla geçmişi olan firmalar olduğu gözlenmektedir (Tablo 7).

\section{Tablo 7. Firmanın Yaşı}

\begin{tabular}{|l|c|c|}
\hline Firmanın yaşı & Sıklık & Yüzde (\%) \\
\hline $0-5$ yıl & 21 & 15,9 \\
\hline $6-10$ yll & 22 & 16,7 \\
\hline $11-15$ yll & 21 & 15,9 \\
\hline $16-20$ yll & 24 & 18,2 \\
\hline $21-25$ yll & 14 & 10,6 \\
\hline 25 ve üzeri yll & 30 & 22,7 \\
\hline Toplam & $\mathbf{1 3 2}$ & $\mathbf{1 0 0}$ \\
\hline
\end{tabular}


İşletmelerin faaliyet alanına bakıldığında \% 78'inin yalnız ulusal pazara yönelik faaliyetlerinin olduğu, yaklaşık beşte birinin ise hem ulusal pazara hem de yurtdışı pazara yönelik faaliyet yapmakta olan firmalar olduğu gözlenmektedir. Sadece bir firmanın ise ulusal ve yurtdışı faaliyet gösteren bir zincir birimi olduğu görülmektedir (Tablo 8).

\section{Tablo 8. Firmanın Ana Pazarı}

\begin{tabular}{|l|c|c|}
\hline Ana Pazar & Sıklık & Yüzde (\%) \\
\hline Yalnız ulusal pazara yönelik faaliyet yapmaktadır. & 103 & 78,0 \\
\hline Hem ulusal pazara hem de yurtdışı pazara yönelik faaliyet yapmaktadır. & 28 & 21,2 \\
\hline Ulusal ve yurtdışı faaliyet gösteren bir zincir birimidir. & 1 &, 8 \\
\hline Toplam & $\mathbf{1 3 2}$ & $\mathbf{1 0 0}$ \\
\hline
\end{tabular}

İşletmelerin toplam sermaye içindeki Ar-Ge payına bakıldığında yaklaşık beşte ikisinin Ar-Ge payının \% 1'den az olduğu ve yaklaşık yarısının ise \%1-5 arası olduğu görülmektedir. Ar-Ge payı \% 6’dan fazla olanlar yaklaşık \%16’yı oluşturmaktadır (Tablo 9).

\section{Tablo 9. İşletmedeki Ar-Ge Payı}

\begin{tabular}{|c|c|c|}
\hline Ar-Ge Payı & Sıklık & Yüzde (\%) \\
\hline$\% 1$ 'den az & 50 & 37,9 \\
\hline$\% 1-5$ arasi & 61 & 46,2 \\
\hline$\% 6-10$ aras1 & 10 & 7,6 \\
\hline$\% 11$ ve fazlas1 & 11 & 8,3 \\
\hline Toplam & $\mathbf{1 3 2}$ & $\mathbf{1 0 0}$ \\
\hline
\end{tabular}

İşletmelerin Ar-Ge faaliyetleri için herhangi bir kurumdan destek alıp almadıklarına bakıldığında, 75 firmanın hiçbir kurumdan destek almadığı görülmektedir. Diğerleri ise Güney Marmara Kalkınma Ajansı, KOSGEB, Özel işletmeler, TÜBİTAK, Üniversiteler gibi kurumlardan destek aldıklarını belirtmişlerdir (Tablo 10).

\section{Tablo 10. İşletmedeki Ar-Ge Desteği}

\begin{tabular}{|l|c|c|}
\hline Destek Olan Kuruluş & S.klık & Yüzde (\%) \\
\hline Ar - Ge desteği almıyor. & 75 & 56,8 \\
\hline KOSGEB & 26 & 19,7 \\
\hline Özel işletmeler & 17 & 12,9 \\
\hline Yurtışı firmalar & 3 & 2,3 \\
\hline TÜBİTAK & 2 & 1,5 \\
\hline Üniversiteler & 2 & 1,5 \\
\hline Diğer kamu kuruluşları & 7 & 5,3 \\
\hline Toplam & $\mathbf{1 3 2}$ & $\mathbf{1 0 0}$ \\
\hline
\end{tabular}


İşletmelerin inovasyon stratejileri incelendiğinde 74 firma mevcut ürünleri geliştirdiklerini ve tasarım yaptıklarını belirtmişlerdir.3 firmanın ise mevcut ürünleri bire bir taklit ettiği görülmektedir. İşletmelerin yaklaşı dörtte biri pazarda olmayan yeni ürün ve hizmetler oluşturduklarını belirtmişlerdir (Tablo11).

\section{Tablo 11. İşletmelerin İnovasyon Stratejileri}

\begin{tabular}{|l|c|c|}
\hline İnovasyon Stratejileri & Sıklık & Yüzde (\%) \\
\hline Pazarda olmayan yeni ürün ve hizmetler oluşturmak & 35 & 26,5 \\
\hline Mevcut ürünleri geliştirmek ve tasarım yapmak & 74 & 56,1 \\
\hline Mevcut ürünleri birebir taklit etmek & 3 & 2,3 \\
\hline Teknolojilerinin mesleki yetenek ve becerilerden oluşması & 6 & 4,5 \\
\hline $\begin{array}{l}\text { Lider işletmenin (pazar payı, satışları en yüksek olan işletme) girmediği ya da } \\
\text { boş bıraktığı fırsatlardan yararlanmak }\end{array}$ & 9 & 6,8 \\
\hline Cevap verilmemiş & 5 & 3,8 \\
\hline Toplam & $\mathbf{1 3 2}$ & $\mathbf{1 0 0}$ \\
\hline
\end{tabular}

\subsection{2. Ölçeklere Ait Faktör Yapılarının Analizleri}

Çok sayıdaki değişken arasındaki ilişkileri ve bunlar arasındaki örüntüleri ortaya çıkararak, bu değişkenlerin daha küçük faktör kümeleri haline getirilmesini sağlamak amacıyla, sosyal bilimlerde sıklıkla kullanılan bir yöntem olan keşfedici faktör analizi kullanılmıştır.

Çalışma kapsamında toplanan verilerin faktör analizi için uygunluğunu anlamak için Kaiser-Meyer-Olkin örneklem yeterliliği değerine bakılmıştır. Verilerin faktör analizine uygunluğu için örneklem yeterliliği değerinin minimum 0,50 'den büyük olması gerekmektedir (Hair ve diğerleri,2010: 104).

Değişkenler ile ilgili faktörler arasındaki korelasyonları gösteren faktör yüklerinin 0,30 veya 0,40 'tan büyük olması kabul edilebilir olmakla birlikte, 0,50 'den büyük olması daha iyi sonuçlar elde etmeyi sağlamaktadır (Hair ve diğerleri,2010: 117). Bu yüzden bu çalışmada da faktör yükleri için alt sınır 0,50 olarak kabul edilmiştir.

Değişken sayısının 20 ile 50 arasında olduğu durumlarda özdeğer (eigenvalue) kriteri kullanmak en güvenilir yol olduğu için (Hair ve diğerleri,2010: 111).Faktör sayısını belirlemek için özdeğer (eigenvalue) kriteri kullanılmıştır ve sadece özdeğeri 1'den büyük olan faktörler dikkate alınmıştır.

\subsubsection{1. İnovasyon Türleri İçin Faktör Analizi}

İnovasyon türleri ölçeğinde toplam yirmi soru ifadesine yer verilmiştir. Yapılan keşfedici faktör analizi sonucunda 1 ve 9 numaralı sorular düşük faktör yükleri sebebiyle analizden 
çıkartılmıştır. Tablo 12'de görüldüğü üzere, yapılan faktör analizi sonucunda dört faktör elde edilmiştir. Bu dört faktör varyansın 60,53'ünü temsil etmektedir. Tablo 12'de 18 soruya ait faktör yükleri yalnızca ifadelerin yüklendiği faktörlere ilişkin olarak gösterilmiştir.

Tablo 12. İnovasyon Türleri İçin Keşifsel Faktör Analizi ve Faktör Yükleri

\begin{tabular}{|c|c|c|}
\hline & & $\begin{array}{c}\text { F aktör Yük- } \\
\text { leri }\end{array}$ \\
\hline \multicolumn{2}{|l|}{ Ürün İnovasyonu } & \\
\hline \multicolumn{2}{|l|}{ Tür2 } & ,714 \\
\hline \multicolumn{2}{|l|}{ Tür3 } & ,758 \\
\hline \multicolumn{2}{|l|}{ Tür4 } & ,745 \\
\hline \multicolumn{2}{|l|}{ Tür5 } & ,681 \\
\hline \multicolumn{2}{|l|}{ Tür6 } & ,794 \\
\hline \multicolumn{2}{|l|}{ Tür7 } &, 511 \\
\hline \multicolumn{3}{|l|}{ Pazarlama İnovasyonu } \\
\hline \multicolumn{2}{|l|}{ Tür12 } &, 567 \\
\hline \multicolumn{2}{|l|}{ Tür13 } & ,606 \\
\hline \multicolumn{2}{|l|}{ Tür14 } & 685 \\
\hline \multicolumn{2}{|l|}{ Tür15 } & ,749 \\
\hline \multicolumn{2}{|l|}{ Tür16 } & ,745 \\
\hline \multicolumn{3}{|l|}{ Organizasyonel İnovasyon } \\
\hline \multicolumn{2}{|l|}{ Tür17 } & ,621 \\
\hline \multicolumn{2}{|l|}{ Tür18 } &, 569 \\
\hline \multicolumn{2}{|l|}{ Tür19 } & ,722 \\
\hline \multicolumn{2}{|l|}{ Tür20 } & ,708 \\
\hline \multicolumn{3}{|l|}{ Süreç İnovasyonu } \\
\hline \multicolumn{2}{|l|}{ Tür8 } &, 540 \\
\hline \multicolumn{2}{|l|}{ Tür10 } &, 771 \\
\hline \multicolumn{2}{|l|}{ Tür11 } & ,791 \\
\hline \multicolumn{2}{|l|}{ Toplam Açıklanan Varyans } & $\% 60,98$ \\
\hline \multicolumn{2}{|c|}{ Kaiser-Meyer-Olkin Örneklem Yeterliliği Ölçüsü } & 0,834 \\
\hline \multirow[t]{3}{*}{ Bartlett's Test of Sphericity } & Yaklaşık Ki-kare & 993,93 \\
\hline & Serbeslik Derecesi & 153 \\
\hline & Anlamlılık & 000 \\
\hline
\end{tabular}

\subsubsection{Güvenilirlik Analizleri}

Araştırmada kullanılan ölçeklerin güvenilirliğini belirlemek için, ölçeklerin içsel tutarlılıkları ölçülmüştür. Araştırmada yararlanılan ölçeklerin güvenilirlik katsayılarının 
0,700 ile 0,851 arasında değerler aldığı görülmektedir (Tablo 13). Güvenilirlik katsayılarının 0,70’ten büyük olması, çalışmada kullanılan ölçeklerin güvenilir olduğunu göstermektedir (Hair ve diğerleri,2010: 125).

\section{Tablo 13. Ölçeklere Ait Güvenilirlik Katsayıları}

\begin{tabular}{|c|c|c|}
\hline DEĞİŞKENLER & Soru sayısı & Alfa Katsayısı ( $\alpha$ ) \\
\hline \multicolumn{3}{|l|}{ İçsel Engeller } \\
\hline Organizasyonel Engeller & 7 & 0,825 \\
\hline Çalışanların Yetersizliği & 3 & 0,730 \\
\hline Yönetsel Engeller & 3 & 0,738 \\
\hline Kaynak Yetersizliği & 3 & 0,753 \\
\hline Bilgi ve Yöntem Eksikliği & 3 & 0,705 \\
\hline \multicolumn{3}{|l|}{ Dişsal Engeller } \\
\hline Sektördeki Ekonomik Engeller & 6 & 0,851 \\
\hline Sektörel İnovasyon Politikaları & 7 & 0,840 \\
\hline Ortaklık ve İşbirliği Eksikliği & 4 & 0,758 \\
\hline Pazardaki Talep Yetersizliği & 4 & 0,700 \\
\hline \multicolumn{3}{|l|}{ İnovasyon Türleri } \\
\hline Ürün İnovasyonu & 6 & 0,830 \\
\hline Pazarlama İnovasyonu & 5 & 0,808 \\
\hline Organizasyonel İnovasyon & 4 & 0,753 \\
\hline Süreç İnovasyonu & 3 & 0,717 \\
\hline
\end{tabular}

\subsubsection{Hipotez Testleri}

Araştırma kapsamındaki hipotezleri test etmek amacıyla çoklu regresyon analizi kullanılmıştır. Çoklu regresyon analizi iki veya daha fazla tahmin değişkenlerinin kullanıldığı regresyon analizidir ve amacı regresyon denkleminin parametrelerinin değerlerini saptamaktır. Araştırma kapsamındaki regresyon modelleri SPSS 20.0 istatistik paket programı ile analiz edilmiş, elde edilen sonuçlar ve hipotezlerin testleri aşağıda sırası ile açıklanmıştır. 
Katılımcıların işletmelerinin inovasyon düzeyinin alınan Ar-Ge desteğine göre değişip değişmediği analiz edildiğinde (Tablo 14), Ar-Ge desteği alan işletmelerin sadece pazarlama inovasyonu ortalamasının destek almayan işletmelerin ortalamasından yüksek olduğu (sırasıyla, 3,82 ve 3,48 ) ve yapılan t-test sonucunda bu ifadeye verilen cevapların ortalamaları arasında istatistikî olarak anlamlı bir fark olduğu görülmektedir $(\mathrm{p}>0,05)$.

Tablo14. İnovasyon Düzeylerinin Alınan Ar-Ge Desteğine Göre Analiz Sonuçları

\begin{tabular}{|c|c|c|c|c|c|c|c|c|c|}
\hline & Ar-Ge Desteği & $\mathbf{N}$ & Ortalama & $\begin{array}{c}\text { Std. } \\
\text { Sapma }\end{array}$ & F & Sig. & t & df & $\begin{array}{c}\text { Sig. } \\
\text { (2-tailed) }\end{array}$ \\
\hline \multirow{2}{*}{ Ürün } & Destek almıyor & 75 & 2,61 & 1,00 & 0,237 & 0,627 & $-1,160$ & 130 & 0,248 \\
\hline & Destek Alıyor & 57 & 2,82 & 0,98 & & & $-1,164$ & 122,2 & 0,247 \\
\hline \multirow{2}{*}{ Pazarlama } & Destek almıyor & 75 & 3,48 & 0,95 & 0,655 & 0,420 & $-2,144$ & 130 & 0,034 \\
\hline & Destek Alıyor & 57 & 3,82 & 0,83 & & & $-2,182$ & 127,1 & 0,031 \\
\hline \multirow{2}{*}{ Organizasyonel } & Destek almıyor & 75 & 3,22 & 1,00 & 0,058 & 0,810 &,- 070 & 130 & 0,945 \\
\hline & Destek Alıyor & 57 & 3,23 & 0,96 & & &,- 070 & 123,3 & 0,944 \\
\hline \multirow{2}{*}{ Süreç } & Destek almıyor & 75 & 3,29 & 0,96 & 0,113 & 0,738 &,- 959 & 130 & 0,339 \\
\hline & Destek Alıyor & 57 & 3,46 & 1,02 & & &,- 950 & 116,0 & 0,344 \\
\hline
\end{tabular}

Katılımcıların işletmelerinin inovasyon düzeyinin alınan Ar-Ge payına göre değişip değişmediği analiz edildiğinde, Ar-Ge payı yüksek olan işletmelerin pazarlama inovasyonu ortalamasının diğerlerinden yüksek olduğu görülmektedir (Tablo 15) ve yapılan ANOVA analizi sonucunda bu değişkenin ortalamaları arasında istatistikî olarak anlamlı bir fark olduğu görülmektedir $(\mathrm{p}=0,006)$. İşletmelerin Ar-Ge’ye ayırdıkları pay arttıkça pazarlama inovasyonu düzeylerinin de arttığı görülmektedir. 
Tablo15. İnovasyon Türleri Düzeyinin Alınan Ar-Ge Payına Göre Analiz Sonuçları

\begin{tabular}{|c|c|c|c|c|c|}
\hline & Ar-Ge Payı & $\mathbf{N}$ & Ort. & $\begin{array}{c}\text { Std. } \\
\text { Sapma }\end{array}$ & Sig. \\
\hline \multirow{4}{*}{ Ürün İnovasyonu } & $\%$ l'den az & 50 & 2,61 & 0,88 & \multirow{4}{*}{0,625} \\
\hline & $\% 1-5$ arası & 61 & 2,69 & 1,07 & \\
\hline & $\% 6-10$ arası & 10 & 2,93 & 1,07 & \\
\hline & $\% 11$ ve fazlası & 11 & 2,97 & 1,08 & \\
\hline \multirow{4}{*}{ Pazarlama İnovasyonu } & $\%$ l'den az & 50 & 3,32 & 0,83 & \multirow{5}{*}{0,006} \\
\hline & $\% 1-5$ arası & 61 & 3,70 & 0,87 & \\
\hline & $\% 6-10$ arası & 10 & 4,08 & 1,07 & \\
\hline & $\% 11$ ve fazlası & 11 & 4,16 & 1,00 & \\
\hline \multirow{4}{*}{ Organizasyonel İnovasyon } & $\%$ l'den az & 50 & 3,06 & 0,92 & \\
\hline & $\% 1-5$ aras 1 & 61 & 3,20 & 0,95 & \multirow{3}{*}{0,101} \\
\hline & $\% 6-10$ aras 1 & 10 & 3,64 & 1,26 & \\
\hline & $\% 11$ ve fazlası & 11 & 3,73 & 1,02 & \\
\hline \multirow{4}{*}{ Süreç İnovasyonu } & $\%$ l'den az & 50 & 3,20 & 1,06 & \multirow{4}{*}{0,347} \\
\hline & $\% 1-5$ arası & 61 & 3,47 & 0,83 & \\
\hline & $\% 6-10$ arası & 10 & 3,23 & 1,03 & \\
\hline & $\% 11$ ve fazlası & 11 & 3,66 & 1,32 & \\
\hline
\end{tabular}

Katılımcıların işletmelerinin inovasyon düzeylerinin inovasyon stratejilerine göre değişip değişmediği analiz edildiğinde, firmanın takip ettiği stratejiye göre inovasyon düzeylerinin değiştiği görülmektedir (Tablo 16). Yapılan ANOVA analizi de bu farkların istatistikî olarak da anlamlı olduğunu göstermektedir $(\mathrm{p}<0,05)$. Pazarda olmayan yeni ürün ve hizmetler oluşturma stratejisini izleyen işletmelerin tüm inovasyon türlerinin ortalamalarının diğer stratejileri izleyen firmalara göre yüksek olduğu görülmektedir. Benzer şekilde "Lider işletmenin girmediği ya da boş bıraktığı firsatlardan yararlanmak" stratejisini izleyen işletmelerin de tüm inovasyon türlerinde yüksek ortalamaya sahip olduğu belirlenmiştir. "Mevcut ürünleri birebir taklit etmek" stratejisini izleyen işletmelerin ise tüm inovasyon türlerinde en düşük ortalamalara sahip olduğu görülmektedir. Mevcut ürünleri birebir taklit etmek stratejisini izleyen işletmelerin da pazarlama inovasyonu ve organizasyonel inovasyon türlerinin ortalamasının eşit olduğu belirlenmiştir. 


\section{Tablo16. İnovasyon Düzeylerinin İnovasyon Stratejilerine Göre Analiz Sonuçları}

\begin{tabular}{|c|c|c|c|c|c|}
\hline & Strateji & $\mathbf{N}$ & Ort. & $\begin{array}{c}\text { Std. } \\
\text { Sapma }\end{array}$ & Sig. \\
\hline \multirow{5}{*}{ Ürün İnovasyonu } & Pazarda olmayan yeni ürün ve hizmetler oluşturmak & 35 & 3,26 & 1,03 & \multirow{5}{*}{0,003} \\
\hline & Mevcut ürünleri geliștirmek ve tasarım yapmak & 74 & 2,5 & 0,94 & \\
\hline & Mevcut ürünleri birebir taklit etmek & 3 & 2,06 & 0,19 & \\
\hline & $\begin{array}{l}\text { Teknolojilerinin mesleki yetenek ve becerilerden oluş- } \\
\text { ması }\end{array}$ & 6 & 2,5 & 1,05 & \\
\hline & $\begin{array}{l}\text { Lider işletmenin girmediği ya da boş bıraktığı fırsatlar- } \\
\text { dan yararlanmak }\end{array}$ & 9 & 2,63 & 0,95 & \\
\hline \multirow{5}{*}{$\begin{array}{l}\text { Pazarlama } \\
\text { İnovasyonu }\end{array}$} & Pazarda olmayan yeni ürün ve hizmetler oluşturmak & 35 & 3,99 & 0,98 & \multirow{5}{*}{0,006} \\
\hline & Mevcut ürünleri geliştirmek ve tasarım yapmak & 74 & 3,63 & 0,81 & \\
\hline & Mevcut ürünleri birebir taklit etmek & 3 & 2,67 & 0,76 & \\
\hline & $\begin{array}{l}\text { Teknolojilerinin mesleki yetenek ve becerilerden oluş- } \\
\text { ması }\end{array}$ & 6 & 2,83 & 0,82 & \\
\hline & $\begin{array}{l}\text { Lider işletmenin girmediği ya da boş bıraktığı fırsatlar- } \\
\text { dan yararlanmak }\end{array}$ & 9 & 3,44 & 0,77 & \\
\hline \multirow{5}{*}{$\begin{array}{l}\text { Organizasyonel } \\
\text { İnovasyon }\end{array}$} & Pazarda olmayan yeni ürün ve hizmetler oluşturmak & 35 & 3,6 & 0,9 & \multirow{5}{*}{0,016} \\
\hline & Mevcut ürünleri geliştirmek ve tasarım yapmak & 74 & 3,07 & 0,96 & \\
\hline & Mevcut ürünleri birebir taklit etmek & 3 & 2,67 & 0,95 & \\
\hline & $\begin{array}{l}\text { Teknolojilerinin mesleki yetenek ve becerilerden oluş- } \\
\text { ması }\end{array}$ & 6 & 2,73 & 0,96 & \\
\hline & $\begin{array}{l}\text { Lider işletmenin girmediği ya da boş bıraktığı fırsatlar- } \\
\text { dan yararlanmak }\end{array}$ & 9 & 3,71 & 0,9 & \\
\hline \multirow{5}{*}{ Süreç İnovasyonu } & Pazarda olmayan yeni ürün ve hizmetler oluşturmak & 35 & 3,66 & 0,9 & \multirow{5}{*}{0,006} \\
\hline & Mevcut ürünleri geliştirmek ve tasarım yapmak & 74 & 3,29 & 0,87 & \\
\hline & Mevcut ürünleri birebir taklit etmek & 3 & 2,25 & 1,25 & \\
\hline & $\begin{array}{l}\text { Teknolojilerinin mesleki yetenek ve becerilerden oluş- } \\
\text { ması }\end{array}$ & 6 & 2,5 & 1,33 & \\
\hline & $\begin{array}{l}\text { Lider işletmenin girmediği ya da boş bıraktığı fırsatlar- } \\
\text { dan yararlanmak }\end{array}$ & 9 & 3,72 & 1,01 & \\
\hline
\end{tabular}

KOBİ’lerdeki firma büyüklügünün işletmelerinin inovasyon düzeyleri üzerindeki etkisine bakıldığında, işletmelerin çalışan sayısına bağlı olarak pazarlama ve süreç inovasyonu düzeylerinin değiştiği görülmektedir (Tablo 17). Yapılan ANOVA analizleri bu farkların istatistikî olarak da anlamlı bir fark olduğunu göstermektedir ( $\mathrm{p}>0,05)$. Pazarlama inovasyonunun ortalamasının, 101'den fazla çalışanı olan firmalarda en yüksek düzeyde olduğu ve firma büyüklükleri arasındaki farkın istatistiksel olarak $(p=0,028)$ önemli olduğu görülmektedir. Çalışan sayısı 26 ile 50 arasında olan işletmelerin ise en düşük 
pazarlama inovasyonu ortalamalarına sahip olduğu görülmektedir. Benzer şekilde süreç inovasyonunun da 101'den fazla çalışanı olan firmalarda en yüksek düzeyde olduğu ve firma büyüklükleri arasındaki farkın istatistiksel olarak $(\mathrm{p}=0,036)$ önemli olduğu görülmektedir.

Tablo17. İnovasyon Düzeyinin KOBİ’lerdeki Firma Büyülklüğüne (Çalışan Sayısı) Göre Analiz Sonuçları

\begin{tabular}{|c|c|c|c|c|c|}
\hline & Firma Büyüklüğg̈i & $\mathbf{N}$ & Ort. & $\begin{array}{c}\text { Std. } \\
\text { Sapma }\end{array}$ & Sig. \\
\hline \multirow{4}{*}{ Ürün İnovasyonu } & $10-25$ arası & 62 & 2,77 & 0,92 & \multirow{4}{*}{0,393} \\
\hline & $26-50$ aras 1 & 35 & 2,48 & 1,15 & \\
\hline & $51-100$ arası & 17 & 2,94 & 1,07 & \\
\hline & $101-249$ aras1 & 18 & 2,67 & 0,82 & \\
\hline \multirow{4}{*}{ Pazarlama İnovasyonu } & $10-25$ aras 1 & 62 & 3,61 & 0,78 & \multirow{4}{*}{0,028} \\
\hline & $26-50$ aras 1 & 35 & 3,31 & 1,02 & \\
\hline & $51-100$ arası & 17 & 3,93 & 1,09 & \\
\hline & $101-249$ aras1 & 18 & 3,99 & 0,77 & \\
\hline \multirow{4}{*}{ Organizasyonel İnovasyon } & $10-25$ aras 1 & 62 & 3,29 & 0,89 & \multirow{4}{*}{0,532} \\
\hline & $26-50$ aras 1 & 35 & 3,07 & 1,03 & \\
\hline & $51-100$ arası & 17 & 3,08 & 1,09 & \\
\hline & $101-249$ aras 1 & 18 & 3,42 & 1,11 & \\
\hline \multirow{4}{*}{ Süreç İnovasyonu } & $10-25$ aras 1 & 62 & 3,36 & 0,81 & \multirow{4}{*}{0,036} \\
\hline & $26-50$ arasi & 35 & 3,25 & 1,1 & \\
\hline & $51-100$ arası & 17 & 3 & 1,26 & \\
\hline & $101-249$ arası & 18 & 3,92 & 0,85 & \\
\hline
\end{tabular}

KOBİlerin yaşları ile inovasyon düzeyleri arasındaki ilişkiye bakıldığında, işletmelerin yaşının inovasyon düzeyleri üzerinde etkisi olmadığı görülmektedir (Tablo 18). İnovasyon türleri üzerine firma yaşının istatistiksel olarak önemli olmadığ $(\mathrm{p}>0,05)$ belirlenmiştir. 
Tablo18. İnovasyon Düzeylerinin KOBİ’lerde Firma Yaşına Göre Analiz Sonuçları

\begin{tabular}{|c|c|c|c|c|c|}
\hline & Firma Yaşı & $\mathbf{N}$ & Ort. & $\begin{array}{c}\text { Std. } \\
\text { Sapma }\end{array}$ & Sig. \\
\hline \multirow{6}{*}{ Ürün İnovasyonu } & $0-5$ yil & 21 & 2,76 & 1,20 & \multirow{6}{*}{0,540} \\
\hline & $6-10$ yil & 22 & 2,89 & 1,09 & \\
\hline & $11-15$ yil & 21 & 2,33 & 0,96 & \\
\hline & $16-20$ yll & 24 & 2,78 & 1,08 & \\
\hline & $21-25$ y1l & 14 & 2,64 & 0,86 & \\
\hline & 25 yıl ve üzeri & 30 & 2,74 & 0,76 & \\
\hline \multirow{6}{*}{ Pazarlama İnovasyonu } & $0-5$ yll & 21 & 3,32 & 1,24 & \multirow{6}{*}{0,304} \\
\hline & 6-10 y1l & 22 & 3,77 & 0,90 & \\
\hline & $11-15$ yil & 21 & 3,61 & 0,95 & \\
\hline & $16-20 \mathrm{y} 1 \mathrm{l}$ & 24 & 3,93 & 0,68 & \\
\hline & $21-25$ yll & 14 & 3,48 & 0,74 & \\
\hline & 25 yıl ve üzeri & 30 & 3,56 & 0,85 & \\
\hline \multirow{6}{*}{ Organizasyonel İnovasyon } & $0-5$ yll & 21 & 3,10 & 1,28 & \multirow{12}{*}{0,308} \\
\hline & $6-10 \mathrm{yll}$ & 22 & 3,00 & 1,06 & \\
\hline & $11-15$ yll & 21 & 3,02 & 0,92 & \\
\hline & $16-20 \mathrm{yil}$ & 24 & 3,43 & 0,87 & \\
\hline & $21-25$ yll & 14 & 3,64 & 0,82 & \\
\hline & 25 yll ve üzeri & 30 & 3,25 & 0,85 & \\
\hline \multirow{6}{*}{ Süreç İnovasyonu } & $0-5$ yil & 21 & 3,40 & 1,28 & \\
\hline & 6-10 yil & 22 & 3,27 & 0,79 & \\
\hline & $11-15$ yil & 21 & 2,98 & 1,05 & \\
\hline & $16-20$ yil & 24 & 3,70 & 0,87 & \\
\hline & $21-25$ yll & 14 & 3,59 & 0,74 & \\
\hline & 25 yll ve üzeri & 30 & 3,29 & 0,97 & \\
\hline
\end{tabular}

KOBI’lerin faaliyet gösterdikleri sektörler hizmet ve üretim sektörü olarak ele alınarak inovasyon düzeyleri ile ilişkisine bakıldığında, üretim işletmelerinin ürün inovasyonu ortalamasının (ort. $=2,91)$ hizmet işletmelerinden (ort. $=2,50)$ fazla olduğu görülmektedir. Hizmet ve üretim sektöründe yer alan işletmelerin ürün inovasyonu düzeyleri arasındaki farkın istatistikî olarak da anlamlı bir fark olduğu görülmektedir (Tablo 19). Hizmet ve üretim sektöründe yer alan firmalar arasında diğer inovasyon türleri açısından istatistiksel olarak anlamlı bir fark olmadığı görülmektedir ( $\mathrm{p}>0,05)$. 
Tablo 19. İnovasyon Düzeylerinin Faaliyet Gösterilen Sektöre Göre Analiz Sonuçları

\begin{tabular}{|c|c|c|c|c|c|c|c|c|c|}
\hline & Ar-Ge Desteği & $\mathbf{N}$ & Ortalama & Std. Sapma & $\mathbf{F}$ & Sig. & $\mathbf{t}$ & df & $\begin{array}{l}\text { Sig. } \\
\text { (2-tailed) }\end{array}$ \\
\hline \multirow[b]{2}{*}{ İnovasyon } & Üretim & 65 & 2,91 & 1,02 & 0,275 & 0,601 & 2,45 & 130 & 0,015 \\
\hline & Hizmet & 67 & 2,50 & 0,93 & & & 2,45 & 128,1 & 0,015 \\
\hline \multirow[t]{2}{*}{ Pazarlama } & Üretim & 65 & 3,73 & 0,87 & 0,311 & 0,578 & 1,29 & 130 & 0,199 \\
\hline & Hizmet & 67 & 3,52 & 0,95 & & & 1,29 & 129,5 & 0,198 \\
\hline \multirow[t]{2}{*}{ Organizasyonel } & Üretim & 65 & 3,22 & 0,97 & 0,003 & 0,957 & $-0,06$ & 130 & 0,947 \\
\hline & Hizmet & 67 & 3,23 & 1,00 & & & $-0,06$ & 129,9 & 0,947 \\
\hline \multirow{2}{*}{ Süreç İnovasyon } & Üretim & 65 & 3,41 & 0,86 & 8,088 & 0,005 & 0,52 & 130 & 0,600 \\
\hline & Hizmet & 67 & 3,32 & 1,10 & & & 0,52 & 124,6 & 0,598 \\
\hline
\end{tabular}

Katılımcıların işletmedeki görevleri ile işletmelerin inovasyon düzeyleri arasında ilişki olup olmadığı analiz edildiğinde, işletme sahibi olan katılımcıların işletmelerinin inovasyon ortalamasının diğerlerinden düşük olduğu görülmektedir (Tablo 20). Ancak yapılan ANOVA analizi sonucunda bu ifadeye verilen cevapların ortalamaları arasında istatistikî olarak anlamlı bir fark olmadığg görülmektedir ( $p>0,05)$.

Tablo 20. İnovasyon Düzeyinin İşletmedeki Göreve Göre Analiz Sonuçları

\begin{tabular}{|c|c|c|c|c|c|}
\hline & İşletmedeki Görev & $\mathbf{N}$ & Ort. & Std.Sapma & Sig. \\
\hline \multirow{3}{*}{ Ürün İnovasyonu } & İşletme Sahibi / Ortağ 1 & 69 & 2,71 & 1,03 & \multirow{3}{*}{0,540} \\
\hline & Üst Kademe Yönetici & 29 & 2,61 & 0,94 & \\
\hline & Orta Kademe Yönetici & 34 & 2,76 & 0,98 & \\
\hline \multirow{3}{*}{ Pazarlama İnovasyonu } & İşletme Sahibi / Ortağ & 69 & 3,53 & 0,90 & \multirow{3}{*}{0,304} \\
\hline & Üst Kademe Yönetici & 29 & 3,73 & 0,96 & \\
\hline & Orta Kademe Yönetici & 34 & 3,71 & 0,90 & \\
\hline \multirow{3}{*}{ Organizasyonel İnovasyon } & İşletme Sahibi / Ortağı & 69 & 3,06 & 1,00 & \multirow{3}{*}{0,308} \\
\hline & Üst Kademe Yönetici & 29 & 3,36 & 1,05 & \\
\hline & Orta Kademe Yönetici & 34 & 3,44 & 0,85 & \\
\hline \multirow{3}{*}{ Süreç İnovasyonu } & İşletme Sahibi / Ortağ1 & 69 & 3,25 & 0,94 & \multirow{3}{*}{0,211} \\
\hline & Üst Kademe Yönetici & 29 & 3,32 & 1,15 & \\
\hline & Orta Kademe Yönetici & 34 & 3,63 & 0,90 & \\
\hline
\end{tabular}




\section{SONUÇ VE ÖNERİLER}

Günümüzde küreselleşme ile birlikte artan rekabet ortamında faaliyet gösteren işletmeler ayakta kalabilmek, varlıklarını sürdürebilmek, rekabet edebilmek ve müşteri ihtiyaçlarına cevap verebilmek için inovasyon kavramına önem vermek zorundadırlar. Sürdürülebilir rekabet avantajı sağlamak, bunu koruyabilmek için işletmelerin ürün, süreç, pazarlama, organizasyon gibi inovasyon türlerini sürekli geliştirme ve yenileme ihtiyaçları bulunmaktadır. KOBİlerin inovasyon uygulama sürecinde çeşitli güçlüklerle karşılaşmaları söz konusudur. Dolayısıyla ilk atılması gereken adım inovasyon engellerinin belirlenmesi ve sınıflandırılmasıdır. Bu durum inovasyon çalışmalarında önemli rol oynamaktadir.

Çanakkale İli ve çevresinde yapılan araştırma sonuçlarına göre aşağıdaki bulgulara ulaşılmıştır:

$\checkmark$ Çanakkale'de faaliyette bulunan KOBİ’lerin büyük bir kısmı inovasyon stratejisi olarak, savunmaya yönelik stratejiyi uygulamaktadırlar. İlgili KOBİler rekabet gücü elde etmek için, mevcut ürünleri geliştirip tasarım yapmaktadırlar.

$\checkmark$ KOBİlerin büyük bir kısmının inovasyon uygulamalarına yönelik olarak; herhangi bir kurumdan Ar-Ge desteği almadığı belirlenmiştir. İşletmelerin çoğunluğunun ise KOSGEB, özel firmalar, yurt dışı firmalar, TUBİTAK, Üniversiteler, Güney Marmara Kalkınma Ajansından Ar-Ge desteği aldıkları görülmektedir. KOBİlere sağlanan destek ve hibelerden faydalanma potansiyelinin yükseltilmesi gerekmektedir.

$\checkmark$ KOBİ'lerin Ar-Ge çalışmaları yapmamaları nedenlerinin; kaynak yetersizliği, bilgi eksikliğive ihtiyaç duyulmamasının olabileceği düşünülmektedir. Ayrıca yapılan mülakatlar sonucunda çoğu KOBİ’de Ar-Ge departmanlarının çok az olduğu görülmektedir.

$\checkmark$ Araştırma sonucunda KOBİ’lerin büyük bir kısmının yalnız ulusal pazara yönelik faaliyette bulunduğu belirlenmiştir.

$\checkmark$ KOBİlerin inovasyon düzeyinin alınan Ar-Ge payına göre değişip değişmediği analiz edildiğinde, Ar-Ge payı yüksek olan işletmelerin pazarlama inovasyonu ortalamasının diğerlerinden yüksek olduğu görülmektedir. İşletmelerin Ar-Ge’ye ayırdıkları pay arttıkça pazarlama inovasyonu düzeyleri artış göstermektedir.

$\checkmark$ KOBİlerin takip ettiği inovasyon stratejisine göre inovasyon düzeyleri de değişmektedir. Pazarda olmayan yeni ürün ve hizmetler oluşturma stratejisini izleyen işletmelerin tüm inovasyon türlerinin ortalamalarının diğer stratejileri izleyen işletmelere göre yüksek olduğu görülmektedir. Mevcut ürünleri birebir taklit etmek” stratejisini izleyen işletmelerin ise tüm inovasyon türlerinde en düşük ortalamalara sahip olduğu ortaya çıkmıştır.

$\checkmark$ KOBİ’lerdeki işletme büyüklüğünün işletmelerin inovasyon düzeyleri üzerindeki 
etkisine bakıldığında, işletmelerin çalışan sayısına bağlı olarak pazarlama ve süreç inovasyonu düzeylerinin değiştiği görülmüştür.

$\checkmark$ KOBİ’lerin yaşları ile inovasyon düzeyleri arasındaki ilişki incelendiğinde, işletmelerin yaşının inovasyon düzeyleri üzerinde etkisinin olmadığı ortaya çıkmıştır. İnovasyon türleri üzerine işletme yaşının istatistiksel olarak önemli olmadığı anlaşılmıştır.

$\checkmark$ KOBİ’lerin faaliyet gösterdikleri sektörler hizmet ve üretim sektörü olarak ele alınarak inovasyon düzeyleri ile ilişkisine bakıldığında, üretim işletmelerin ürün inovasyonu ortalamasının, hizmet işletmelerinden fazla olduğu görülmektedir.

$\checkmark$ Katılımcıların işletmedeki görevleri ile işletmelerin inovasyon düzeyleri arasında ilişki incelendiğinde, işletme sahibi olan katılımcıların işletmelerinin inovasyon ortalamasının diğerlerinden düşük olduğu görülmektedir.

$\checkmark$ İşletmelerin toplam sermaye içindeki Ar-Ge payının düşük olduğu tespit edilmiştir.

$\checkmark$ İşletme sahip ve yöneticilerinin çoğunluğunun eğitim düzeylerinin üniversite seviyesinde olduğu görülmektedir. Bu ise Ar-Ge yaparak geliştirmeyi düşünen kişi sayısının var olması açısından önemlidir. Ancak bu potansiyele sahip kişilerin Ar-Ge yapma yöntemleri konusunda eğitilmeleri ve yönlendirilmeleri yerinde olacaktır.

Yapılan araştırma bulgu ve değerlendirmelere göre; aşă̆ıda belirtilen öneriler getirilmiştir:

$\triangleright$ KOBİlerin karşılaştığı en önemli engelleri; rekabet engeli, finansal erişim, enerji fiyatı, teknoloji, verimsiz üretim maliyeti, ekonomik faktörler, yönetim becerisi, süreç, satış kısıtlamalarıdır. KOBİler işlerine destekleyici teknoloji satın almak için uygun krediyle teknoloji ile desteklemelidir.

$\triangleright$ KOBİlerin ayakta kalmalarına yardımcı olmak için destekleyici bir politikaya ihtiyacı vardır. KOBİ’leri geliştirmek için ciddi programlar yürütülmesi, örneğin yurt dışı pazarlama, beceri ve bilgi gelişimi ve girişimci motivasyon eğitimi verilmesi gerekmektedir.

$\triangleright$ Bölgede ihracatı geliştirmek ve desteklemek için KOBİ'ler de teknoloji inovasyonun geliştirilmesi önemlidir. Teknoloji inovasyonu ihracatçıların maliyet inovasyonu yoluyla düşük maliyet yapısı oluşturmasına veya yüksek seviyede ürün farklılığına imkân tanıyacaktır.

DÜniversitenin işletmelere İnovasyon, Ar-Ge, girişimcilik konularında bilgilendirici seminerler vermesi zayıf olan yönlerin güçlendirilmesi açısından önemlidir. Çanakkale ilinde bulunan teknopark imkânlarından yeterince faydalanılması gerekmektedir.

DPazar çeşitlendirilmesi için KOBİlere destek olunması gerekmektedir. KOBİlerin ulaşamadığı pazarlar incelenip, elde edilen sonuçların KOBİlere aktarılması önem 
taşımaktadır.

$\triangleright$ Bankaların inovatif KOBİ'leri daha fazla desteklemesi, KOBİlerin inovasyon ve Ar-Ge kapasitelerinin artırılmasını sağlayacaktır.

Bu çalışma Çanakkale’de faaliyette bulunan KOBİlerde ilk kez yapıldığı için bir başlangıç olarak kabul edilmelidir. Bu çalışmanın ve bulguların en önemli amaçlarından biri de sonraki çalışmalarda araştırmacılara yol gösterici olmasıdır. Bu araştırmada üzerinde durulan, araştırma modeli test edilmelidir. Bu çalışmanın bulgularının, başka şehirlerde yapılacak araştırmaların bulgularıyla kıyaslanması sayesinde KOBİlerin inovasyon tutumları ve engellerine yönelik çıkarımlar yapmak da mümkün olacaktır. 


\section{KAYNAKÇA}

Aksoy, A. ve Demirel, E.T.(2008). Yenilik Faaliyetleri Açısından KOBİ’ler. E-Journal of New World Sciences Academy, 3(3): 391-408.

Aslan, M.(2014). İnovasyon Düşünmenin Zirvesi. İstanbul: FinalYayıncılık.

Birasnav M.,Albufsala, M. ve Bader, Y.(2013). The Role of Transformational Leader ship and Knowledge Management Processes on Predicting Product and Process Innovation: An Empirica 1Study Developed in Kingdom of Bahrain. Reviev of Applied Management Studies. 11: 64-75.

Burmaoğlu,S. ve Şeşen,H.(2011). Türk İşletmelerinin Organizasyonel İnovasyon Yeteneğini Etkileyen Faktörler Üzerine Bir Araştırma. Ankara Üniversitesi SBS Dergisi. 66(4): 1-20.

Bozkurt, Ö.Ç. ve Kalkan, A. (2014). Business Strategıes of SMEs, Innovatıon Typ and Factors Influencing their Innovatıon: Burdur Model. Ege Akademik Bakış. 14(2): 189198.

Deniz,M.(2011). KOBİ’lerde Yenilik, Yenilik Stratejileri ve Bir Uygulama. S.Ü. İ.I.B.F Sosyal ve Ekonomik Araştırmalar Dergisi. 22: 142-175.

Elçi,Ş.(2006). İnovasyon Kalkınmanın ve Rekabetin Anahtarı. Ankara: Nova Basım Yayın Dağıtım.

Güleş,H. K.ve Bülbül,H.(2004). İnovasyon İşletmelerin Stratejik Rekabet Aracı. Ankara: Nobel Yayınları

Günay,Ö.(2007). KOBİlerde Yenilik Türlerinin Analizi ve Yenilik Engellerinin Belirlenmesine Yönelik Bir Araştırma.(Yüksek Lisans Tezi ). İstanbul: İstanbul Üniversitesi Sosyal Bilimler Enstitüsü.

Gündüz, E.(2012).Rekabet Geriliminin Stratejik İnovasyona Etkisinin Farkındalık Motivasyon ve Yetenek Perspektifinde İncelenmesi.(Doktora Tezi). İstanbul: İstanbul Üniversitesi Sosyal Bilimler Enstitüsü.

Hair, Jr., Black, W.C., Babin, B.J. Anderson, R.E., (2010). Multivariate Data Analysis. (7th ed.). NJ: Englewood Cliffs.Prentice Hall.

Işık, C. ve Keskin, G.(2013). Bilgi Ekonomilerinde Rekabet Üstünlüğü Oluşturulması Açısındanİnovasyonun Önemi. Atatürk Üniversitesi İ.̇.B.F. Dergisi. 27(1): 41-57.

İraz,R.(2005). Yaratıcılık ve Yenilik Bağlamında Girişimcilik ve KOBİ’ler, Çizgi Kitabevi, Konya.

Kalkan,A., Bozkurt, Ö. Ç. ve Kılınç, O. (2012). The Relatıon Shıps Between Sector Where SME's Operatıng and Their Strategies Innovation Types\&Innovation Barriers. Journal of Global Strategic Management: 103-112.

Keskin, S. (2012). İnovasyon Nasıl Yapılır?İstanbul: Mavi Yayınları. 
Kılıç, R. (2011). Küçük ve Orta Büyüklükteki İsletmelerde Bir Özyetenek Oluşturma Stratejisi Olarak İnovasyon: Balıkesir İli ve Çevresinde Bir Araştırma. (Yayınlanmış Doktora Tezi). Isparta: Süleyman Demirel ÜniversitesiSosyal Bilimler Enstitüsü.

Kotey,B. ve Sorensen,A. (2014). Barriers to Small Business Innovationin Rural Australia. Australasian Journal of Regional Studies. 20(3): 405-429.

Laforet, S.(2013).Organizational Innovation out Comesin SMEs: Effects of Age, Size, and Sector. Journal of World Business. 48: 490-502.

Marangoz, M.(2012).Girişimcilik. İstanbul: Beta Yayınları.

Naidoo,V. (2010). Firm Survival Through ACrisis: The Influence of Market Orientation, Marketing Innovation and Business Strategy. Industrial Marketing Management. 39: 1311-1320.

Robinson,S. ve Stubberud,H.A. (2012). Issues In Innovation for Norwegian Smes. Journal of International Business Research. 11(1): 53-61.

Rosenbusch,N.,Brinckmann, J. ve Bausch, A. (2011). Is Innovation Always Beneficial? A Meta-Analysis of the Relationship Between Innovation and Performance in SMEs. Journal of Business Venturing.26: 441-457.

Sattayaraksa,T.veSakun,B.(2015).AstudyofCEOTransformationalLeadership,Organizational Factors and Product Innovation Performance: Scale Development and a Theoretical Framework.7(2): 107-125.

Satı,Z.E.(2013). İnovasyonu Yönetmede Kesitler. Ankara:Nobel Yayınları.

Soto,J. D. (2016). Technological, Management, and Persistent Innovation in Small and Medium Family Firms: The Influence of Professionalism. Journal of Administrative Sciences Revue Canadiennedes Sciences de l'administration. 33: 332-346.

Subrahmanya,B.(2015). Innovation and Growth Engineering SMEs in Bangalore: Why do only Some Innovate and Only Some Grow Faster?.Journal of Engineering and Technology Management. 36: 24-40.

Taşkın, E. ve Kahraman, H. (2016). KOBİlerdeki İnovasyonu Arttırmada Pazar Yönlülük, Girişimci Yönlülük Ve İşletmeler Arası İşbirliğinin Bütünsel Etkisi. Dumlupınar Üniversitesi, Sosyal Bilimler Dergisi. Afro- Avrasya Özel Sayısı: 535-555.

Tavassoli,S. ve Karlsson,C. (2015). Persistence of Various Types of Innovation Analyzed and Explained.Research Policy. 44: 1887-1901.

Tokmak, İ.(2008). Stratejik İnsan Kaynakları Yönetiminin İşletmelerin Yenilikçilik Yeteneğine Etkisi ve Elektronik Sanayisine Yönelik Bir Araştırma. (Doktora Tezi). Sakarya Üniversitesi Sosyal Bilimler Enstitüsü.55-58,109-110.

Ülgen,H. ve Mirze,K. (2004). İşletmelerde Stratejik Yönetim. İstanbul: Literatür Yayınları. 